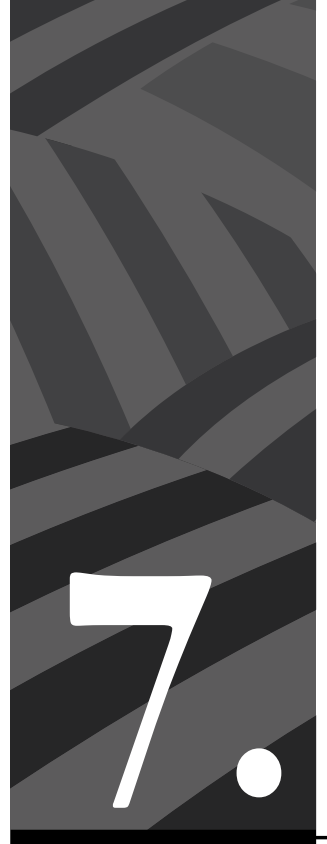

Entre leyes, mingas e historia oral 


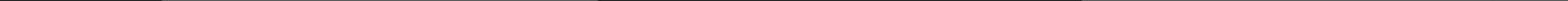




\section{Entre leyes, mingas e historia oral*}

Por Oscar Andrés López Cortés** y Tulio Rojas Curieux***

Porque las luces que parecían ser verdes se volvieron negras, los politiqueros son los que se han hecho dueños de la comunidad.

Salomón Cuaical 12 de octubre de 2006, Cumbal.

\section{Introducción}

La Constitución de 1991 reconoció formalmente a los pueblos indígenas en Colombia una serie de derechos políticos negados sistemáticamente durante las diferentes fases republicanas. Algunos de estos derechos han permitido a los pueblos aumentar la participación en los espacios de deliberación de políticas públicas, acceder a recursos y administrarlos de manera autónoma; así como también han permitido a las comunidades diseñar y ejercer sus propios mecanismos de resolución de conflictos, entre otros aspectos determinantes para la preservación de la diversidad étnica y cultural. No obstante, este reconocimiento jurídico también ha generado cuestionamientos entre los académicos, activistas sociales y las propias comunidades, en tanto que se han agudizado conflictos propios de las luchas por el ejercicio del poder y el acceso a los recursos económicos entre los mismos pueblos.

Desde esta perspectiva, ilustraremos algunos de los conflictos emergentes entre dos grupos predominantes en el pueblo de los Pastos, ubicados

* $\quad$ Artículo recibido en septiembre de 2015

Artículo aprobado en noviembre de 2015

** Abogado. Docente Investigador de jornada completa en el Centro de Investigaciones Socio Jurídicas de la Facultad de Derecho de la Universidad Libre. Bogotá.

*** Lingüista. Profesor Departamento de Antropología, Facultad de Ciencias Humanas y Sociales de la Universidad del Cauca. Popayán. 
en Cumbal (Nariño); esto con el fin de analizar cuáles han sido los impactos concretos que dicho cambio constitucional generó tanto en el gobierno local, como en el manejo del territorio y los mecanismos de resolución de conflictos en el pueblo de los Pastos. Con ello no se pretende descalificar ni subvalorar el reconocimiento legal de los derechos indígenas constitucionalmente reconocidos, como tampoco se busca formular un diagnóstico general acerca de las condiciones de existencia de los pueblos indígenas en Colombia.

De hecho, buscamos promover una reflexión de contexto útil para la discusión que al respecto han adelantado miembros de esa comunidad.

\section{Reconstruir el contexto}

En la zona que hoy comprende la frontera entre el departamento de Nariño (Colombia) y la provincia del Carchi (Ecuador) habita, desde épocas prehispánicas, el pueblo de los Pastos. Después de la constitución de estas repúblicas suramericanas, el pueblo enfrentó los proyectos de nación que ellas representaban, lo que ocasionó enfrentamientos con el ejército de Bolívar (Gutiérrez, 2007). Sobre los Pastos existe abundante literatura reunida en trabajos de antropología e historia ${ }^{1}$, la cual da cuenta, entre otras cosas, de una prolífica tradición oral, a través de la cual este pueblo ha mantenido la memoria sobre aspectos trascendentales que aquí analizaremos; como, por ejemplo, el proceso de construcción del reglamento interno. Otro aspecto importante que los narradores orales Pastos destacan de su historia - aunque no siempre

1 González Suárez, 1902; Mejía, 1934; Pérez, 1958; Cifuentes, 2004; Martínez, 1977; Rappaport, 2005; Digges y Rappaport, 1993; Landázuri, 1990; Muñoz, 1982, 2004, 2011, 2012; Solarte y colaboradores, 1998; Chamorro, 1982; Guerrero, 1998; Cerón y Zarama, 2003, López, 2016; Groot de Mahecha y Hooykas, 1991; Uribe, 1986; Moreno, 1999. Sobre: Historia del arte, Guerrero (2012); Arqueología, Gómez (1985); Geohrafía humana, Mamian (1996 y 2004); Relatos de cronistas, Arteaga (1910) y Cieza de León (1962). 
tenido en cuenta por la literatura académica sobre este grupo ${ }^{2}$ - es el proceso de recuperación de tierras, en el que hábilmente ellos conjugaron diversas estrategias: toma de posesión mediante las vías de hecho y reclamaciones legales basándose en títulos reales de propiedad sobre las tierras otorgados a la comunidad indígena.

Mediante el reconocimiento y simultánea negación del derecho estatal, los Pastos usan la lógica del pensamiento jurídico moderno occidental al tiempo que construyen concepciones propias de justicia, lo que genera una interesante aunque riesgosa combinación. Riesgosa si tenemos en cuenta lo planteado por diversos trabajos a propósito de las consecuencias del multiculturalismo en la vida política de los pueblos indígenas en centro y sur América, como se puede observar en los trabajos de Van Cott (2000), Wade (2006), Gros (2012), Briones (1998) y Lemaitre $(2009)^{3}$. Reflexiones pertinentes en el caso de los Pastos, en tanto el reconocimiento jurídico estatal, porque han girado en torno a la entrada de dineros públicos a las comunidades, lo que a su vez ha forjado divisiones internas, disputas y clientelismo.

En un contexto de agudización de las problemáticas socio-económicas, olvido estatal y crecimiento del narcotráfico y la guerra, desde hace tres décadas, los Pastos adelantan discusiones en búsqueda de la conformación de su ley o reglamento interno, pues con ella se materializaría lo que algunos llaman el Derecho Mayor o propio. Tales acepciones son indistintamente empleadas por líderes, viejos recuperadores, miembros del Cabildo, integrantes del Consejo Mayor y la comunidad en general ${ }^{4}$.

2 Respecto a las tensiones que surgen entre la historia oficial y la historia oral de los Pastos se sugiere revisar López, 2016.

3 En tanto no es nuestro objetivo ocuparnos del debate sobre el multiculturalismo, sugerimos a los lectores remitirse a López 2011b.

4 En Cumbal se habla con frecuencia de los viejos recuperadores como una forma respetuosa a través de la cual se reconoce a los hombres - casi nunca a las mujeres- que lideraron el proceso de recuperación de tierras durante la década de los años setenta y ochenta del siglo XX. 
Este proceso y sus implicaciones son recordados por Omar Chiran, participante activo de muchas de las reuniones convocadas para la construcción del reglamento interno, entre ellas la celebrada el 2 de agosto de 2009:

[...] desde el año 2006 que estaba como gobernador don Hernando Peregüeza y luego en el año 2007, se inicia la construcción de la ley interna o también se le llama el reglamento interno, pero se ha dicho que este nombre no se le debería dar, nosotros hablaremos de esa ley interna como Derecho Mayor. En ese proceso desde esos años es lo que se está creando, en la misma Constitución del 91 se da facultad a las comunidades para que creen sus propias leyes, para no regirnos a las leyes de afuera. Como colombianos bajo las leyes que nos regimos son las del Estado, pero como pueblos indígenas nosotros tenemos que tener una autoridad propia y también normas y leyes propias por nosotros mismas creadas. En nuestra ley se consagra cómo queremos que funcione la educación, la salud, el territorio, nosotros como queremos y podemos mediante una ley propia administrar nuestro territorio ${ }^{5}$.

Al hablar del derecho, las leyes y la justicia entre los Pastos, la memoria y los mitos reunidos en la historia oral se constituyen en fuentes de elaboración del Derecho Mayor ${ }^{6}$. Sin embargo, definirlo como derecho ha implicado para los Pastos un debate en múltiples aspectos. Por ejemplo, cuál es el sentido de justicia que esa forma de derecho debe realizar, el papel de la autoridad, el territorio, la identidad, la conservación de

5 Omar Chiran. Sesión realizada el 2 de agosto de 2009 en la institución educativa Machines de la vereda Tasmag.

$6 \quad$ Los mitos como expresiones narrativas en el caso de los Pastos, tienen una importancia central en la manera como este pueblo construye el orden simbólico a través del cual dan sentido a muchas de sus prácticas culturales. Los principales mitos en el caso de los pastos describen a dos brujos (el Guangas y el Chispas) o a dos perdices (la blanca y la negra) que simbolizan el origen del territorio y quienes lo habitan, así como los pares complementarios constitutivos de las principales dualidades: el arriba y el abajo, lo frío y lo caliente, entre otras. Dumer Mamián (1996 y 2004) ha analizado el papel de los mitos en el pueblo de los pastos. 
la memoria, el valor de las tradiciones, entre otros. En cuanto a la autoridad, para algunos narradores, esta se puede recuperar a través del Derecho Mayor: "La herramienta fuerte es la organización con nuestra autoridad, pues hoy las peleas son internas, por individualismo. El reglamento nos permitirá llevar las cosas en orden, determinar el cuidado de nuestra naturaleza; no hemos sido compatibles en la ideología. La recuperación por la tierra y la defensa de nuestros derechos deben ser compatibles, pues se busca la unidad de las comunidades indígenas"?.

Los valores que la comunidad identifica como fundamentales podría recuperarse también a través de una Ley interna que recoja los principios del Derecho Mayor:

Surge la iniciativa de la Ley Interna, por la razón de existir inconvenientes, deterioro de la autoridad, la organización, la administración, la madre tierra, los recursos naturales y la justicia; además por la necesidad de promover y fortalecer la educación, la medicina propia y demás valores y principios que están en peligro de degradarse en razón de la introducción externa de factores que debilitan nuestra cultura. Pero también por causas internas, como la falta de capacitación en nuestros valores, principios y prácticas ancestrales ${ }^{8}$.

Los procesos organizativos de los Pastos han provocado disputas. Estas reflejan las tensiones y retos más importantes de este pueblo, pues son producto de las transformaciones políticas y jurídicas ocurridas durante

7 Luis Cuaspud. Intervención de apertura en el taller del 12 de octubre de 2006. A lo largo del texto se mencionarán los talleres, mesas de trabajo y rondas de socialización realizadas entre los años 2006 a 2011 por el pueblo de los Pastos residente en Cumbal, que tuvieron como propósito, entre otros, la creación del reglamento interno. El lector podrá encontrar en el acápite siguiente: "Sobre el método empleado”, una explicación del origen de las fuentes etnográficas aquí empleadas.

8 Conclusión de la mesa de trabajo "Autoridad, Administración y justicia Indígena". Realizada en Cumbal en el mes octubre de 2007. 
las últimas décadas. Las tensiones en mención resultan comprensibles si se tiene en cuenta la relación entre sociedad mayoritaria y pueblos indígenas en el marco del multiculturalismo. El proceso de identificación del Derecho Mayor en Cumbal, de hecho, las ilustra, de allí que resulte pertinente narrar la historia de cómo ha sido este proceso y cuál es el contexto sociopolítico más amplio de la discusión.

El proceso de conformación de un sistema de derecho como conjunto de reglas y procedimientos para resolver los conflictos de los Pastos refleja las rupturas que el multiculturalismo jurídico puede provocar entre la comunidad. En Cumbal se perciben dos tendencias en cuanto al contenido del Derecho Mayor: el carácter de sus fuentes, es decir, sus orígenes, y las formas institucionales a las cuales debería dar lugar. Un grupo se atribuye haber sido el promotor y líder del proceso de identificación y recuperación de la autoridad por la vía del Derecho Mayor, pero el otro alega lo mismo. Unos reclaman la potestad de definir el sentido de la ley de origen; los otros también. En medio de estas pugnas, ambos grupos buscan la potestad de definir cuál es el verdadero derecho.

Nuestra hipótesis afirma que el multiculturalismo se constituye como un dispositivo de seguridad que crea una cesura entre lo decible y lo indecible, por el cual se ejerce control sobre la palabra indígena. De esa manera, el estado multicultural no compone una forma de desregulación y consecuente libertad de los pueblos, aunque tampoco de dominación y absoluta restricción, sino de regulación flexible o porosa, que da una mayor sensación de libertad. Es importante señalar al respecto que, como estrategia, esto permite al Estado adaptarse a las nuevas demandas de los movimientos sociales y, al tiempo, normalizar y domesticar las diferencias ${ }^{9}$.

9 Respecto al concepto de normalizar, o efecto de la normalización, remitirse a Rabinow (2008). 


\section{Sobre el método empleado}

Las voces que el lector encontrará en este artículo se recogieron entre los años 2006 y 2009, época en la cual se realizaron varias reuniones para la creación del reglamento interno. Las discusiones de esos encuentros quedaron consignadas en diferentes actas, a las cuales tuvimos acceso gracias a la generosidad de miembros de la comunidad, quienes nos permitieron leer las memorias de lo ocurrido en aquellos años. De manera distinta ocurrió con las reuniones realizadas entre 2010 y 2011, que presenciamos con la aceptación del Consejo Mayor de Cumbal para tomar un registro de lo ocurrido. Cabe recordar que en estas reuniones se realizaron talleres en los que participamos intercambiando reflexiones a propósito de las tensiones entre derecho estatal y el Derecho Mayor de los Pastos, razón por la cual no pretendemos presentar una perspectiva objetiva de lo ocurrido. Por el contrario, nuestro relato y el análisis que lo acompaña está cargado de la subjetividad que estos encuentros produjeron.

\section{La historia del reglamento interno}

En el año 2006 comenzó en Cumbal el proceso de creación del reglamento interno. El Cabildo estaba encabezado por el gobernador Hernando Peregüeza, quien junto a un grupo de líderes inició las reuniones con el objetivo de debatir la construcción del reglamento, el cual debía reflejar los principios, valores, tradiciones y el sentido de justicia propio de los Pastos. La comunidad, a través del Cabildo, adelantó unos talleres con la participación de líderes, viejos recuperadores, cabildantes, excabildantes, estudiantes universitarios, profesionales, entre otros. Para tal efecto, se organizaron convocatorias en cada vereda a través de perifoneo, comenzando, como lo ordena la tradición, por la vereda de Guan.

La iniciativa surgió entre el Cabildo de entonces y la Shaquiñan -Asociación de Cabildos y Autoridades Tradicionales del Nudo de los Pastos, 
liderada entonces por Efrén Tarapues $-{ }^{10}$. De esa manera, las dos organizaciones pusieron en marcha los talleres en las distintas veredas del resguardo. Dichas actividades debían recoger las impresiones de la comunidad a propósito de sus costumbres y tradiciones, lo que permitiría entender el sentido de justicia propio de los Pastos.

Una vez comenzaron los talleres aparecieron nuevas temáticas y problemáticas para discutir. Debates sobre representación política, manejo de dineros públicos, integración del Cabildo, mecanismos de elección de las autoridades, entre otros asuntos, se traslapaban con intervenciones que aludían a la colonización, el deterioro ambiental, la recuperación de los territorios y la existencia de las leyes de origen. Las temporalidades entre un presente concreto se trenzaban con distintos pasados, algunos remotos para la temporalidad occidental, pero determinantes para la historia presente de la organización sociopolítica de los Pastos. Luego de las discusiones, los participantes consideraron necesario recoger en el reglamento interno mecanismos de solución a tales problemáticas, estos debían corresponder a las formas de Derecho Mayor propias de los Pastos. De allí surge la necesidad de crear una norma que recogiera los valores de la comunidad como soporte del sentido de justicia, y también se propuso la creación de un organismo independiente del Cabildo encargado de hacer cumplir el reglamento.

Esto manifestaba uno de los participantes del taller realizado en el Llano de Piedras:

De mi parte, hago presencia como miembro del Consejo Mayor de la vereda Quilismal, y así lo andamos haciendo desde que iniciamos en Guan, en el recorrido y en la socialización del reglamento interno, como es importante para el orden del resguardo, para cuando estamos en las contiendas electoreflexión académica y recuperación de la tradición, con el objetivo de conservar el pensamiento propio y la cultura ancestral. 
rales, para las corporaciones, para tener un mayor orden en todo sentido, porque esto no es capricho aquí del Consejo Mayor o del honorable Cabildo. [...] Es una obligación que tenemos nosotros de acuerdo a nuestros usos y costumbres, como hemos vivido: tenemos que seguir haciendo respetar nuestros derechos a los estados. Nuestros mayores, nuestros antepasados antiguamente para defender los derechos, los mayores para que nos reconocieran a nosotros como indígenas, se daban la paciencia, se iban a pie a Bogotá o para Quito a reclamar nuestros derechos. Hoy de esa manera ya no lo hacemos, pero más sin embargo tenemos que tener un orden y un reglamento interno aquí en el resguardo ${ }^{11}$.

La creación del reglamento interno resultó un proyecto trascendental para la comunidad, especialmente para el sector liderado por Shaquiñan y algunos de los líderes de la recuperación de tierras ocurrida durante los años setenta y ochenta del siglo XX. El reglamento interno se proyectaba como algo más que un compendio normativo, se trataba de una propuesta de constitución política propia, de una ley de origen a través de la cual los Pastos expresarían su sentido de justicia, preservarían el territorio y sus tradiciones culturales, mejorarían la gobernabilidad, castigarían los delitos y las ofensas, entre otros objetivos. Como se comprende de la cantidad de metas trazadas, se trataba - y aún se trata- de un proyecto ambicioso, para el cual sería necesario contar con el apoyo de la comunidad y de las autoridades propias; en particular, del Cabildo.

La estrategia empleada por este grupo, que convocaba a viejos protagonistas de la recuperación de tierras con jóvenes líderes de Cumbal, resultaba ser una potente combinación de movilización y conversación, marcha y asamblea o como ellos mismos lo expresaron: de minga. Esto señalaba Fidencio Alpala, un participante del taller realizado en el Llano de Piedras en el 2011:

$11 \quad$ Participante en el taller del Llano de Piedras. 
Los invitamos a que aprovechemos al máximo este importante debate, a esta minga convocada para formular nuestro reglamento indígena, que solo así podremos identificarnos y ordenar esta importante vereda, y como ahí mismo lo dice, legalizar y sanear nuestro territorio. Entonces de ustedes depende, amigos líderes.

A lo que otro asistente del mismo taller respondió:

Sabemos que nuestra ley es de origen, nuestra ley propia nos hace falta, aquí hay ex-gobernadores, y los regidores miramos que en realidad la Ley interna hace falta. El Gobierno Nacional mismo pregunta que "cuál es la ley de ustedes como cabildo, como resguardo", y nosotros hasta el momento no hemos tenido nada. Pero poco a poco, despacio, como vamos viendo la vamos a tener y vamos a darle una continuidad, y en su momento tendrá su legitimidad por la misma comunidad.

Así surgió la Ley Interna el 25 de noviembre de 2009, primer documento que recogía el trabajo adelantado entre 2006 y 2009, suscrito por quienes entonces eran el gobernador del Cabildo, Ponciano Cuaical, y el presidente del Consejo Mayor, don Salomón Cuaical. De este documento de tres capítulos y cuarenta y dos artículos destacamos el artículo treinta y tres, fragmento que reúne los ejes fundamentales de la Ley ${ }^{12}$ :

La Justicia Propia, en el caso de la Comunidad Indígena de Cumbal, se fundamentará (sic) en el Derecho Mayor, bajo los siguientes aspectos:

12 El nombre completo dado al documento fue: Ley interna Derecho Mayor del resguardo del Gran Cumbal. "Por la cual se regulan las funciones de las autoridades indígenas, la creación del Consejo Mayor, las elecciones de la Corporación del Cabildo, la población y el censo del resguardo del Gran Cumbal”. En adelante será citado como: Ley interna. Aclaramos que no se trata de un documento legal expedido por el Estado colombiano ni por ninguna otra autoridad de carácter público, sino un documento derivado de la autonomía indígena o del gobierno propio de los Pastos. 
a) La justicia indígena en base al Derecho Mayor es una justicia que nace, permanece y se trasmite a través del pensamiento o memoria de las comunidades y pueblos.

b) Es una justicia ancestral, basada en la Ley de Origen, Ley Natural, Pensamiento Propio, la espiritualidad y es sagrada.

c) Promueve la justicia desde la madre tierra, la naturaleza, la comunidad, la cultura, la organización, el equilibrio, la equidad y la armonía.

d) Es la forma de mantener el orden de todo cuanto existe, para bien de la vida y la prolongación de la existencia.

e) Es una justicia pública, oral, de sanación y corrección corporal, mental y espiritual.

Aquí se destaca la consagración de la justicia como forma de sanación y corrección corporal, que dista de ser, al menos en su consagración normativa, una forma de justicia punitiva. Así, antes que castigar, la intención de la Ley Interna es buscar el equilibrio tanto del individuo como del territorio, esto expresado a través de la metáfora de la sanación o corrección corporal. Tanto en los talleres como en las rondas de socialización, los intervinientes insistieron en la necesidad de sanear el territorio, expresión alusiva tanto al espacio físico como a sus ocupantes.

Otro elemento relevante es el papel de la memoria recreada a través de la historia oral, pues representa el pensamiento transmitido generacionalmente a través de los relatos. Así se consagró en las discusiones adelantadas para la creación de la Ley en lo relativo a la definición del Derecho Mayor:

Derecho Mayor: Es la madre tierra porque es el origen de todo ser viviente, es pensamiento, es comunidad, es usos y costumbres, es la oralidad. Este es un derecho prioritario en la comunidad indígena de Cumbal que contiene los derechos ya mencionados, es el pilar de todos los derechos indígenas y constitucionales. Porque este se ha preservado y mantenido gracias a la lucha de nuestros mayores ${ }^{13}$.

13 Ley Interna 
Lucha y naturaleza, como elementos fundantes del Derecho Mayor, son pilares que se emplean con frecuencia en el vehículo de transmisión y resignificación, es decir, en la historia oral. Por un lado, el territorio, la autoridad y la autonomía, han sido alcanzados y recuperados a través de la lucha, la cual se evoca permanentemente mediante un conjunto de relatos épicos ubicados en distintas temporalidades. Por otro, la naturaleza es construida a través de la historia mítica cuyo fundamento es el equilibrio y la reciprocidad entre las dualidades complejas y complementarias del arriba y el abajo, el Guangas y el Chispas, lo frío y lo caliente, la perdiz negra y la perdiz blanca.

Otro elemento destacable se encuentra en el artículo 14 de la Ley, pues en él se reconoce como autoridades en Cumbal, en primer lugar, a la comunidad y, en segundo, a la Corporación del Cabildo, el Consejo Mayor y los excabildantes. Los redactores del reglamento buscaban garantizar dos aspectos diversos pero complementarios, propuestos en las mesas de trabajo conformadas desde el 2007: la comunidad rige por encima del Cabildo, pues, aunque se configure como autoridad y ente de gobierno de manera legítima, está al servicio y bajo las órdenes de la comunidad. Este artículo reconoce, además, la importancia de las fuentes vivas de la memoria, por lo cual se debe dar el lugar merecido a los excabildantes y líderes de la comunidad, de manera que sea posible crear una institucionalidad en equilibrio y ejercer control sobre las actuaciones del Cabildo.

El trabajo de organización dio como resultado un documento que señalaba, además de órganos y estructuras, las bases axiológicas coherentes con las tradiciones, las problemáticas, la cultura, los mitos, la historia y los demás aspectos relevantes para la comunidad vinculados con la justicia. En concordancia con esta base, surgió la necesidad de conformar un Consejo de Mayores, o Consejo Mayor, como finalmente sería designado. Se trataba de crear un organismo autónomo e independiente del Cabildo, conformado por personas mayores de 40 años, habitantes del resguardo y con determinadas cualidades: ser excabildantes, reco- 
nocida honorabilidad y no registrar antecedentes. Estas personas debían encarnar los valores propios de los Pastos, conocer su historia y el territorio, para así poder dirimir con equidad los conflictos de la comunidad. Adicionalmente, el Consejo Mayor debía asesorar al Cabildo en lo que fuere necesario, pero de forma independiente.

Uno de los llamados a la importancia de este trabajo, se dio en la ronda de socialización realizada en agosto de 2009:

Como conocedor de este reglamento interno, felicitar a la corporación de hoy que sigan con este proyecto, para que nuestros hijos sean el futuro, para que no exista malas elecciones, malos manejos de los dineros de transferencia. [...] Nosotros empalmamos con el cabildo cesante y nos comprometimos a seguir la formulación de ese reglamento interno, de ahí para acá no sé por qué no se nombró. Pienso que para comenzar lo primero es constituir el Consejo de Mayores, para que de ahí se siga direccionando y con más amplitud y fortaleciendo a la comunidad. El Consejo Mayor es esencial para la comunidad, y sobre todo para el cabildo, pues con el Consejo Mayor hay más respeto ${ }^{14}$.

Los integrantes del Consejo Mayor debían ser independientes frente al manejo político del resguardo. Por eso, durante las discusiones del 2009 a propósito de la expedición del reglamento Interno y la conformación del Consejo Mayor, se debatió la posibilidad de prohibir a sus miembros la participación en política. Al respecto, Álvaro Cuaical señalaba el 2 de agosto de 2009:

Se dice que un miembro del Consejo Mayor no debe hacer proselitismos políticos, desde mi punto de vista no pueden generar una serie de controversias y problemáticas, y si son ellos los primeros en hacer politiquería

14 Segundo Cuatin. Primera ronda de socialización realizada el $1^{\circ}$ de agosto de 2009. Institución Educativa Jorge Eliécer Gaitán, vereda de Guan. Don Segundo fue regidor por esa misma vereda en el 2007. 
entonces en manos de quién se está dejando la planeación y organización; es decir, deben ser imparciales, que den orden, mejoren y replanteen. $\mathrm{Si}$ en una elección el Consejo Mayor tiene una inclinación, su reflexión y posición no debe encontrarse en ninguna de las partes; esto aclara que son libres pero con coordinación, sin generar controversia. Lo que pasó con las anteriores elecciones no es una buena enseñanza, por eso estoy de acuerdo con esa prohibición, porque con el tiempo se pueden presentar inconvenientes. Es necesario que sean ellos los que nos den un ejemplo ${ }^{15}$.

Otra opinión sobre los avances y el debate del reglamento interno fue la expuesta por el señor Luis Mitis en la ronda de socialización llevada a cabo en la vereda de Guan:

Para nosotros los indígenas es bien importante que este reglamento interno siga adelante. Creo que en eso está la mayoría de la comunidad, ella es la máxima autoridad, que es representada por el cabildo, y por ello no es necesario que toda la comunidad esté presente, en algunos otros aspectos y respecto al Consejo Mayor, ellos deberían estar presentes en estas reuniones y de todas formas que exista un respeto ya por ellos, y los del Consejo Mayor a finales del 2007 se presentaron como precandidatos y por ello han perdido credibilidad. Creo que es bueno dialogar sobre las formas de elección, además la comunidad está a la expectativa de sus dirigentes, porque ellos llevarán la voz a ella ${ }^{16}$.

La necesidad de conformar un Consejo Mayor surgió también como una forma de controlar el poder del Cabildo y equilibrar las fuerzas políticas divergentes. Este era uno de los postulados que surgió en la Minga de Pensamiento Cumbe para el Fortalecimiento del Derecho Mayor, realizada el 12 de octubre de 2006 en Cumbal:

Álvaro Cuaical. Segunda ronda de socialización, 2 de agosto de 2009. Institución Educativa Machines de la vereda Tasmag. En esta ronda, Cuaical hace referencia al incidente ocurrido a propósito de las elecciones de Ponciano Cuaical como gobernador del Cabildo para el 2009. 
El Consejo de Mayores sería para dar conceptos sobre el actuar del Cabildo y de los indígenas; porque en el hecho de que el Cabildo haya asumido el poder se puede caer en un gobierno autoritario y tirano por ejercer los tres poderes. El Consejo de Mayores será quien emitirá un concepto más no será el que gobierne y ese concepto será tanto para el Cabildo como para la Comunidad ${ }^{17}$.

La señal es clara: se requiere equilibrar el poder y contar con un órgano que ejerza el control sobre las autoridades que administran recursos económicos. De allí la importancia de las cualidades de quienes integraran el Consejo Mayor.

En medio de muchas dificultades económicas, en su mayoría ocasionadas por rivalidades políticas, se logró consolidar el Consejo Mayor, corporación integrada originalmente por trece personas: dos por cada vereda representada en el Cabildo (Guan, Tasmag, Cuaical, Quilismal, Nazate, Cuaspud) y una más por la emergente vereda del Llano de Piedra, reconocida en el 2009 por el Cabildo como una sección más del resguardo. La intención de integrar el Consejo con dos personas por vereda era la de conformar una corporación que representara las dos corrientes políticas presentes en Cumbal.

Es importante anotar que, aunque hoy en Cumbal no se habla de la existencia de tan solo dos tendencias políticas, durante buena parte del siglo XX la presencia del bipartidismo constituyó la tensión predominante. Esa parece ser la razón por la cual muchos aún hablan de dos tendencias:

El año 1981 se inicia con la recuperación de la Boyera, con la autoridad que con respeto se nombró. Esas elecciones fueron fiel copia auténtica del invasor, quizás sea por tener algunos principios de los europeos, pero

17 Trabajo de Reglamento Minga de pensamiento Cumbe. 
tenemos que buscarle nuevos mecanismos de cómo nombrar nuestra autoridad. Aprendimos del arrellanismo y del figueroismo ${ }^{18}$.

La influencia ejercida por los partidos tradicionales durante casi la totalidad del siglo XX implicó a su vez corrupción, clientelismo y otros vicios propios de la política nacional. Estas prácticas quedaron marcadas en la memoria de líderes como don Salomón Cuaical, quien atribuye a esa influencia la dificultad para consolidar una política propia con base en las tradiciones culturales de los Pastos. Para don Salomón era necesario adoptar un reglamento interno si se quería abandonar las prácticas corruptas incrustadas en la comunidad por los partidos tradicionales. La autonomía debía ser tanto de las autoridades como de la comunidad. Se trataba del reclamo de una cultura política autónoma, libre de clientelismo, corrupción y demás vicios, a los cuales usualmente aludían los participantes de los talleres mediante la expresión: politiquería. Esta la oponían a lo político como un ejercicio de la autonomía, los derechos y la autoridad basada en los designios de la comunidad, el respeto a las tradiciones, la transparencia en el manejo de los recursos y el equilibrio en el territorio:

En los tiempos de adelante en el ejercicio de la autoridad y justicia no se practicaban las formas y vicios de la politiquería, la corrupción, los engaños, las mentiras, entre otros vicios que ocasionan la desorganización comunitaria en todos los aspectos de la vida y causan el desequilibrio social, natural, cultural y político ${ }^{19}$. Estas enfermedades de la organización y la autoridad la inculcaron en la mente de nuestras comunidades los españoles, y se propago más esta contaminación con la incursión de los partidos tradicionales desde la época de la república, año $1810^{20}$.

Salomón Cuaical. Taller del Llano de Piedras. Por arellanismo, don Salomón se refiere a los Arellano, familia de políticos liberales que por mucho tiempo influyó en Cumbal, entre quienes figuraron Laureano Alberto Arellano, ex representante a la Cámara por Nariño. Del figueroismo aludido por don Salomón no se encuentra registro, pero parece aludir al partido conservador presente en esa zona de Nariño. Alusión al pasado, que para muchas comunidades andinas no se encuentra atrás como sucede en la línea cronológica occidental. 
Construir un reglamento interno generó con el tiempo nuevas fracturas. Durante los gobiernos del 2006 y 2007 el Cabildo apoyó la conformación del Consejo Mayor, pero no así el del 2008, pues este cuestionó el proceso al asumir la oposición. Los señalamientos de ilegitimidad e ilegalidad contra el Consejo Mayor provenían del Cabildo, ya que algunos de sus regidores consideraban que la autoridad era exclusiva de su competencia, única corporación reconocida por la Constitución Política, la legislación nacional y la división de etnias del Ministerio del Interior.

No obstante, el Cabildo no podía actuar en contra del Consejo Mayor, ya que sus integrantes eran personas reconocidas por la comunidad, pues a muchos de ellos se les debía la recuperación de las tierras ocurrida durante las décadas del setenta y del ochenta. Como el Cabildo no podía deslegitimar al Consejo Mayor optó por suspender la financiación de los gastos de desplazamiento y alimentación de sus miembros. Aunque todos prestaban su servicio ad honorem, era necesario cubrir gastos básicos de transporte y alimentación de los mayores durante las jornadas de sesión, las cuales se podían extender por un día entero una vez por semana en las veredas cercanas, o hasta dos días en veredas alejadas. Este hecho se discutió años después, como ocurrió durante el taller realizado en Llano de Piedras en el 2011:

Ya en el siguiente año, en el 2008, siendo gobernador don Jaime Asa, dicen que no, que ese reglamento no hay que hacerlo, que cómo van a estar gastándose la plata y dejar de hacer las obras, seguir haciendo las casas comunales, la rutas, y vea, están en mora los tanques de enfriamiento de leche. Bueno, mañana irá a salir otra propuesta, pero muchos nos vamos a quedar de pronto en algún elemento con elefantes muertos porque no están dados hacia una cuestión. Bueno, entonces en el 2008 dicen: ¡hagamos obras!, qué vamos a estar gastándonos la plata en eso de reglamento interno, mayores ¿ustedes quieren reunirse?, reúnanse, pero plata no hay, la plata es pa`obras ${ }^{21}$.

${ }^{21} \quad$ Intervención de Luis Alpala en el taller de Llano de Piedras. 
Pero sí había recursos económicos para otros asuntos. En agosto de 2008, con el auspicio del Cabildo, es publicado el libro de Miguel Ángel Alpala: El Derecho Mayor en el Pueblo Indígena de los Pastos. En este documento, el autor señala lo siguiente:

El Derecho Mayor es una normatividad que no prescribe y proviene del cuento, mito, leyenda, rituales, sueños, dichos, del Quendo, del Yagé, de la lucha, de los mártires indígenas y nuestros mayores lo transformaron en una Cosmovisión sólida, propia, del como miraron su propio mundo (Alpala, 2008, p. 25).

La invocación de las múltiples fuentes a las que Alpala atribuye el origen del Derecho Mayor, contrasta con su carácter no prescriptivo pero sí normativo. Las fuentes aludidas por el autor no se reducen a una normatividad o a un conjunto de prescripciones; en su perspectiva ambas tradiciones -iusnaturalista y positivista- conviven en el Derecho Mayor. Resulta entonces llamativo el proceso descrito por el autor: en el texto jamás se alude al Consejo Mayor, ni a las actividades adelantadas durante 2006 y 2007 para la conformación del reglamento interno. Mediante su silencio, el proceso ocupa el lugar de lo que nunca ocurrió. A lo que sí alude el autor es a la Escuela de Derecho Propio Laureano Inampues, a la cual él pertenece. Alpala defiende la importancia que tuvo la escuela en la conformación del Derecho Mayor:

Para darle un balimento [título] especial al Derecho Mayor, las comunidades del pueblo Pasto han puesto en marcha la Escuela de Derecho Propio Laureano Inampues, con el fin de achicular [articular] los derechos ancestrales y mirar con profundidad el horizonte de los pueblos indígenas y no caer en el sustentáculo de los occidentales, buscar otra alternativa para aplicar la ley, para no reprimir al hombre en el desdén de la desolación y la ignorancia; los jueces, gobernadores, concejos, tribunales y la alta Corte Constitucional Indígena, llamada hacer cumplir la justicia deben ser hombres de paz, que utilicen la diplomacia para que la gente los mire como amigos, no como verdugos, que sepan aplicar el derecho al derecho (Alpala, 2008, p. 41). 
Hay un contraste con la postura indigenista en las afirmaciones según las cuales las instituciones que deben representar a los indígenas son jueces, gobernadores, concejos, tribunales y la alta Corte Constitucional Indígena. Con estas alusiones se hace eco de las instituciones conformadas en el derecho estatal. Igualmente destacable es el nombre dado a la institución de promoción ideológica y a su cometido, Escuela de Derecho, cuya matriz se ubica en la forma del derecho que es enseñado, y no producto de la conversación.

El autor establece en su libro las que a su juicio son las Autoridades Tradicionales derivadas del Derecho Mayor: "1. La comunidad, como la máxima autoridad dentro de su jurisdicción, Resguardo o Territorio 2. El gobernador, Cacique y Capitán, cabeza visible de la organización. 3. Regidores. Alguacil, Teniente, Secretario, suplentes que representan un equipo de personas importantes para la defensa de los intereses colectivos” (p.42). De esa manera, Alpala desconoce al Consejo Mayor. El autor sostiene que el texto recoge quince años de investigación y actividad política con la comunidad, no obstante, las actividades de los dos años anteriores y que dieron lugar al Consejo Mayor, no son registrados. Su postura es la de los contradictores del Consejo Mayor: negar su existencia al considerarla una organización espuria para el sistema jurídico nacional. Este hecho lo registran con claridad los integrantes de Shaquiñan:

Entonces digamos que el Consejo Mayor en su momento va a cumplir y ha cumplido un papel importante, al cual nos sigue hoy ese concepto de algunos cabildos y de algunos comuneros de que el Consejo no hace falta; yo lo escuchaba a alguienes de aquí del Llano que cuando estábamos organizando las elecciones llegaban a gritar durísimo que aquí no manda el Consejo y que se están yendo por encima del Cabildo ${ }^{22}$.

En la descripción de Miguel Ángel Alpala se alude de manera ambivalente a un "derecho mayor" que ya existe y se encuentra consolidado,

22 Intervención de Luis Humberto Alpala en el taller de Llano de Piedras. 
aunque se trate de un proceso. Mientras que en la perspectiva de Shaquiñan se reconoce al Derecho Mayor como un proceso en construcción de la mano de la comunidad, en la que el Consejo Mayor juega un papel determinante. Pero esta no será la única diferencia. La Escuela de Derecho Propio Laureano Inampues se ubica en la orilla contraria de Shaquiñan. La primera reivindica el pluralismo jurídico como bandera de su movimiento, ideología mediante la cual promueve la consolidación de la jurisdicción especial indígena:

La Jurisdicción Especial Indígena es resultado de una práctica (sic) remota y cultural cuyo centro es la solución al INTERIOR DE LAS COMUNIDADES de sus conflictos, a partir de la vigencia de la Constitución Política del año de 1991 se reconoce esta práctica como parte de la nueva institucionalidad del país, la cual será ejercida por las autoridades propias y de acuerdo a sus propios usos y costumbres. Esta jurisdicción enriquece el concepto conocido como Pluralismo Jurídico, que implica entre otras cosas que no existe un ÚNICO DERECHO APLICABLE en nuestro país. Sino que existen múltiples sistemas jurídicos que contribuyen a garantizar a ciudadanos también de diversas visiones culturales, la vigencia de un bien jurídico fundamental como es el acceso a la justicia ${ }^{23}$.

Adicionalmente, la Escuela de Derecho Propio señala que su idea del tiempo se opone a la reivindicación de un pasado como fundamento de la identidad: "Desde la reflexión y experiencia de nuestra escuela,

23 Derechos Humanos y Ley de Víctimas. Ley 1448 de 2011 Ley de Víctimas y Restitución de Tierras. Decreto 4633 Reglamentario Ley 1448. Una lectura desde la cosmovisión y pensamiento del pueblo de los Pastos. Programa Conjunto Ventanas de Paz y Asociación de Autoridades Indígenas Pastos. 2012, página 6. (este documento será citado en adelante como Cartilla de Ventanas de Paz, para conservar la manera como los participantes de los talleres se referían al documento. Este documento cartilla fue realizado con el apoyo de la Escuela de Derecho Laureano Inampues, y entre sus redactores se encuentran miembros de la misma. La Asociación de Autoridades de los Pastos es la opositora política de Shaquiñan, aunque sus nombres son casi idénticos. Mayúscula en el texto original. 
el sujeto indígena no se concibe como un asunto del pasado. Menos creemos en esa forma de percibir el tiempo" 24 . Por su parte, Shaquiñan alude permanentemente a los tiempos de adelante, es decir, a lo que en la lectura occidental se entiende como pasado, como el fundamento central del Derecho Mayor; incluso esto es lo que permite considerar al Derecho Mayor como tal. Por último, cabe resaltar la metodología que emplea la Escuela de Derecho: “Ahora bien, en la escuela de Derecho Propio se viene incorporando el enfoque de estudio de caso como la mejor ruta metodológica para el abordaje de problemas complejos como los impactos de las violencias y la vulneración de los derechos humanos de los pueblos indígenas" ${ }^{25}$.

Los estudios de caso - metodología que surge en las universidades norteamericanas y es empleada en centros de formación jurídica y de negocios - se oponen a la metodología propuesta por Shaquiñan, quien sostiene que la minga de pensamiento caminando la palabra quiere decir "recorrer el territorio para llegar a las veredas más distantes de Cumbal, para conversar y recoger las inquietudes de la mayor cantidad posible de participantes”.

En 2009 retornaron las condiciones favorables para el Consejo Mayor con don Ponciano Cuaical, elegido Gobernador del Cabildo para ese año. Aunque este cambio estuvo antecedido por una maniobra política que buscaba obstaculizar la posesión de don Ponciano, quien entró a ejercer solo varias semanas después de lo debido ( $1^{\circ}$ de enero de 2009). Esto porque el contendor derrotado, Alonso Valenzuela -alineado al gobernador del 2008 y próximo a la Escuela de Derecho Laureano Inampues - maniobró para inscribir en la división de etnias en Bogotá su nombre como vencedor en las elecciones ${ }^{26}$.

24 Cartilla Ventanas de Paz, página 4

25 Cartilla Ventnas de Paz, página 6, negrita en el original

26 La dificultad práctica que este detalle técnico ofrece, radica en que los recursos de transferencias se congelan hasta que se tenga claro quiénes conforman el Cabildo, 
La estrategia adelantada por Valenzuela consistió en levantar un acta al final del conteo de los votos con la firma del Alcalde Municipal en la cual se declaraba vencedor contrariando los resultados de las urnas. Este documento fue radicado en la Dirección de Etnias de Ministerio del Interior en Bogotá para la respectiva inscripción, pero a la capital del país también llegó una segunda acta firmada por los cabildantes salientes - los del periodo 2008-, en la cual se constataba que el vencedor había sido Ponciano Cuaical. Ante la situación, la división de etnias le informó al Alcalde Municipal que se abstendría de inscribir el nuevo cabildo en tanto las autoridades indígenas no resolvieran el conflicto. El candidato derrotado impidió la posesión del Cabildo con base en el acta mencionada y generó así un conflicto de gobernabilidad que se extendió durante varias semanas. La costumbre ordena que debe ser el cabildo saliente, no el Alcalde Municipal, quien elabora el acta por medio de la cual se reconoce a los nuevos integrantes.

Resuelto el conflicto a finales de febrero, asumió la gobernación don Ponciano, quien reactivó las actividades del Consejo Mayor. El proceso por la construcción del reglamento interno continuó durante el 2009 con una ronda de discusiones en cada una de las veredas del resguardo: $1^{\circ}$ de agosto en Guan, 2 de agosto en Tasmag, 6 de agosto en Cuetial, 8 de agosto en Quilismal, 12 de agosto en Cuaspud, 14 de agosto en Boyera, 16 de agosto en San Martín, 27 de agosto en Cuaical, 29 de agosto en Llano de Piedras. Este proceso permitió que el Consejo Mayor se consolidara como la corporación que debía resolver los conflictos de la comunidad y regular el poder del Cabildo, pero sería un acto de Estado lo que más relevancia le daría ante la comunidad.

La discusión en la cual el Consejo de Mayores adquirió mayor relevancia ante la comunidad, se originó con la expedición del Oficio 2400 de septiembre 24 de 2009 realizada por el entonces Instituto Colombiano

y en especial, quién es su gobernador, representante legal para todos los efectos ante las autoridades estatales. (Diarios de campo, febrero de 2009). 
de Desarrollo Rural, Incoder, y la Circular 5060 emitida por el Instituto Geográfico Agustín Codazzi el 3 de noviembre de 2009. En estos documentos se ponían en duda los títulos de los resguardos coloniales y de esa manera se cuestionaba la propiedad de los Pastos sobre gran parte de Cumbal. Luego de ser publicados, el Gobierno Nacional exigió a los pueblos indígenas la reestructuración de los resguardos, lo que implicaba el levantamiento de un nuevo mapa mediante el cual se definiera qué porciones del territorio se encontraban amparados por el título del resguardo, cuáles eran de origen colonial, cuáles de origen republicano y, por último, cuáles predios se encontraban bajo títulos de propiedad privada.

Esta exigencia gubernamental implicaba una amenaza para la comunidad, pues muchos de los predios entregados a los comuneros desde los años ochenta no se encuentran amparados como territorios de resguardo. Las razones son diversas: en algunas se dio porque el mismo Cabildo consideraba que era suficiente con la entrega material del predio hecha por el Cabildo a los comuneros, sin necesidad de legalizar el título ante el Incora, en tanto esa era una dependencia del Estado y no una autoridad de los Pastos. En otras ocasiones los títulos se perdían debido a la falta de archivo del Cabildo, o porque los cabildantes se llevaban los documentos para sus casas al culminar sus periodos. Por último, la falta de claridad en materia de titulación también obedece al levantamiento de escrituras privadas realizado por algunos miembros de la comunidad ante notarías de Ipiales, con el fin de hacer pasar los predios por propiedades privadas y de esa manera obtener créditos hipotecarios para cubrir los gastos de estudio para los hijos, insumos para los cultivos, maquinaria, entre otros. Esta problemática ha sido claramente visualizada por la comunidad en diferentes momentos:

Entonces yo digo, nuestra responsabilidad de visionar el territorio, digamos, en su cuestión mucho más amplia. Tenemos que hablar de este tema de la legalidad, de la ampliación, pero tenemos que hablar de otro tema, quizás aquí dentro del Llano no tanto por ser zona de recuperación, pero 
si en otros lados sucede que siguen existiendo las escrituras; si se hace saneamiento van a preguntar que si usted tiene escritura o documento. $\mathrm{Si}$ es escritura automáticamente lo registran y por el hecho de tenerla pasa a ser un campesino, y no un indígena, y esa va a ser la lectura del Gobierno con esta política que va a aplicar. Por eso si la gente no está preparada para responder eso, o simplemente que se haga escribir ya como campesino ¿cierto? Eso sin decirle a usted si es o no campesino, solo le dicen: ¿escritura o documento?, y a veces como le hace falta la escritura para un crédito, entonces dice yo tengo escritura. Entonces cuando su hijo vaya a ser reclamado por el ejército le dirán que él es campesino. Y lo otro es que como tiene escritura cuando quieran entrar en propiedad privada a extraer el agua y los recursos que quieran sobre una propiedad privada puede intervenir el Estado en cualquier momento, entonces el indio tiene que ser [palabra inaudible], por esa decencia, por ese territorio y por esa recreación de los saberes propios ${ }^{27}$.

La falta de claridad en materia de títulos fragmenta el territorio y cuestiona la propiedad comunal. Adicionalmente, esto le permite al Estado declarar como baldíos aquellos predios carentes de título del resguardo $\mathrm{y}$, de esa manera, fragmentar la autoridad sobre el territorio y dividir a la comunidad. Esta controversia y la presión por una posible reestructuración del resguardo ordenada por el Gobierno Nacional exigían la clarificación de títulos, conducente a demostrar que los predios ocupados por las familias inscritas dentro del censo indígena integran el resguardo. Ante esta problemática fue necesario acudir a la memoria de quienes habían integrado antiguos cabildos, o habían participado en la recuperación de las tierras, y en ese sentido, el Consejo Mayor reunía a varias personas que ostentaban al menos una de esas condiciones.

27 Intervención de Luis Alpala en el taller del Llano de Piedras. Al referirse a documento, Alpala alude a la certificación escrita expedida por el Cabildo y entregada al comunero como constancia de estar ocupando una porción de tierra perteneciente a la comunidad indígena. Este documento hace las veces de una escritura pública, con la diferencia que no transfiere la propiedad sino la posesión. 
Mientras esto ocurría en materia territorial, transcurrieron reuniones, discusiones, trabajos de equipo, socializaciones y caminatas a lo largo de las veredas por espacio de dos años. Los recorridos se extendieron allende las seis parcialidades hasta entonces reconocidas por el Cabildo, a las veredas de San Martín, Boyera y Llano de Piedras, tradicionalmente marginadas en los procesos políticos de $\mathrm{Cumbal}^{28}$. La intención de los participantes era consolidar un espacio de conversación más amplio e incluyente, al tiempo que realizaban un trabajo de cartografía destinado a reconstruir los títulos del resguardo con base en la memoria de los miembros del Consejo Mayor. Al respecto, uno de los asistentes al taller de Llano de Piedras señalaba:

Nosotros sabemos que aquí tenemos inconvenientes, muchos aquí en esta vereda nueva sabemos que hay que legalizar, sanear nuestro territorio, $\mathrm{y}$ esto es que necesitamos aquí que contribuyamos todos en este importante debate. A veces dejamos que esto se haga tarde, y solamente cuando ya nos toca elegir a nuestros representantes entonces los invitamos a que aprovechemos al máximo este importante debate a esta minga de formular nuestro reglamento indígena que solo así podremos identificarnos y ordenar esta importante vereda y, como ahí mismo lo dice, legalizar y sanear nuestro territorio, entonces de ustedes depende, amigos líderes.

De esa manera, la historia oral mediante la cual se recordaba cómo se había recuperado la tierra durante las décadas anteriores, y luego cómo se había distribuido entre los comuneros, permitía enfrentar al Estado que pretendía desconocer los títulos del resguardo. Todo este trabajo se daba mientras se discutía el reglamento interno mediante reuniones de socialización. El documento que contenía el reglamento interno, daba pautas de actuación para el Consejo Mayor, al cual comenzaban a otorgársele importantes responsabilidades en materia de solución de conflictos en Cumbal.

La vereda de San Martín se encuentra ubicada al costado occidental del cerro de Cumbal. Es la vereda más alejada del casco urbano de Cumbal y llegar a ella puede tomar doce horas de caminata. 
No obstante, lo claro que resultaba para los participantes de este proceso la importancia de la conformación del Consejo Mayor, de la expedición de la Ley Interna y demás aspectos vinculados, no era así para algunos miembros de la comunidad ubicados en franca oposición. La fractura que ya se vislumbraba tras los hechos ocurridos en el 2008, se intensificaba en la medida que crecía el número de personas a las cuales llegaban las noticias sobre la expedición de la ley.

Para algunos de los cabildantes de los años 2011 y 2012, cercanos a la Escuela de Derecho Laureano Inampues, no era legítima la actuación del Consejo Mayor ni la Ley Interna expedida en el año 2009. El Cabildo era para ellos la única autoridad legítimamente constituida dentro del resguardo, y con la ruptura que esto representaba se evidenciaban, así, las consecuencias de la política multicultural. Por un lado, el Estado abre espacios de participación jurídica y política mediante la fórmula retórica del pluralismo jurídico. Esto, como sostienen Barona y Rojas (2007), constituye una auténtica falacia mediante la cual se clausura la posibilidad de creación alternativa de derechos y libertades por fuera de los estrictos parámetros marcados por los derechos fundamentales de carácter universal. Por otro lado, genera la esperanza del reconocimiento de la jurisdicción especial indígena, la cual no se alcanza, pues el campo de acción de la misma siempre está cuidadosamente vigilado por la interpretación que de su competencia realizan los órganos judiciales del Estado.

De esa manera opera un sistema de exclusión, sutil pero eficaz, entre lo decible y lo indecible, un sistema de vigilancia poroso y flexible. Se da así la separación entre la palabra por la cual se pronuncia la justicia indígena y el poder que la vigila, la admite, la tolera y, finalmente, la regula. El estado multicultural no constituye una forma de desregulación y consecuente libertad de los pueblos, tampoco un sistema de dominación estricto, sino un mecanismo de regulación dúctil y estratégico. El multiculturalismo realiza una distribución institucional eficiente mediante la cual se coacciona a los otros discursos, coerción que 
puede ser sutil o violenta según lo demande la situación. ¿A qué se le puede llamar justicia, a qué se le puede llamar derecho?, son preguntas que las comunidades creyentes del pluralismo jurídico creen responder por cuenta de un discurso previamente permitido en los espacios antes considerados privilegios de las clases dominantes.

En los últimos años los Pastos ha conquistado importantes espacios de participación política en el Congreso de la República, gobernaciones, alcaldías y los concejos municipales, así como dinero para financiar obras públicas, salud y educación. Pero esto también significa la aparición de apetitos electorales, cuotas burocráticas, clientelismo, participación en contratos y licitaciones; y así es como el multiculturalismo se posiciona para dividir. Ciertamente la entrada de los recursos económicos ha significado la realización de obras importantes, pero también la fractura de valores fundamentales:

Primero había un formato que el ministerio decía de cómo hacer el proyecto; segundo, en ese año, en el 2008, se pagó aquí gente para que no haga nada y no se pagó el asesor técnico para que se haga el proyecto. Se acabó el año y el ministerio dijo: "hermanitos no ejecutaron los proyectos a tiempo", y el gobernador, cuando dijo eso, cogió y trasladó los setenta millones con los proyectos a medio camino y nos quitaron la financiación y el Ministerio dijo chao. ¿Cuál era la visión del Cabildo de ese año?: pues si ya me voy ipara qué voy a dejar proyectos financiado? ¡Egoísmo! Ese es el liderazgo de Cabildo que tenemos. Al Cabildo de Cumbal le otorgaron una licencia, pero esa licencia pasó a proveer unos equipos, o tal vez sostener unos equipos de propiedad privada. Y la emisora se utiliza como propiedad privada para defender intereses bajo su punto de vista, bajo su lógica pero no bajo la visión de la comunidad. Lo que dice el dueño, propietario, gerente, iese es el pensamiento de la comunidad? Uno dice, en esa emisora, iese es el pensamiento comunitario?, zahí se están diciendo cosas verdaderamente de la comunidad?, zahí se informa lo que el Cabildo o la comunidad proyecta? ¡Nunca! Ahí se dicen cosas de interés personal ${ }^{29}$.

29 Intervención de uno de los participantes al taller del 13 de noviembre de 2010. 
Esto se ventilaba nuevamente en el taller del Llano de Piedras:

Si bien es cierto los que lucharon porque vengan los recursos, las transferencias, en el proyecto era para educarnos, así como estamos hablando de nuestros usos y costumbres, nuestra cosmovisión. Pero entonces alguien cogió y se puso a construir escuelas y para eso no venía la plata, alguien se puso a pagar profesores, y para eso no venía la plata y de pronto les dieron malversación a los recursos y ¿dónde estamos?

Hoy los Pastos son mucho más que un movimiento indígena con capacidad para bloquear la vía Panamericana, aunque muchos políticos los siguen viendo como votos para las elecciones. Los gobiernos liberales y conservadores, como recuerda don Salomón Cuaical, se disputaban en Cumbal los votos de los indígenas censados como campesinos, generando incluso fuertes confrontaciones entre ellos. Pero después de la Constitución de 1991, y con el ascenso de las Autoridades Indígenas de Colombia - AICO-, los liberales y conservadores que quieren conseguir votos tienen que sentarse a conversar con senadores, gobernadores departamentales, regidores, diputados, alcaldes y concejales Pastos. Antes también lo hacían con sus líderes, pero hay más dinero sobre la mesa de conversaciones.

El escenario multicultural no parece ser el más adecuado para discutir la conformación de una Ley interna que plasme el sentido de la justicia capaz de representar la diferencia cultural de un pueblo como los Pastos. Por ello, resultan acertadas las palabras de don Salomón Cuaical, participante de la recuperación de la tierra durante las décadas de los setenta y los ochenta:

Si nos unimos volveremos a recuperar el territorio. Hoy 12 de octubre el Gobierno lo considera como el día de la raza, antes de 1492 existieron pueblos milenarios con gobierno propio, pero hay que recordar la historia de quiénes fueron, quiénes llegaron: una tripulación de 120 hombres. Aquí inicia la explotación y aniquilación de la madre tierra, pero la resistencia 
fue grande y se dio hasta hoy en los pueblos indígenas. Anteriormente cuando se pasaba por este callado el candidato o los candidatos eran entrevistados por la comunidad y como pidiéndole el favor de que admita recibir ese cargo; en ese tiempo no había, como hoy se ha dado, lo que lo considero como un escándalo y malgasto de los recursos de transferencia. La comisión la conformaban tres indígenas y estos salían a solicitarle a la comunidad por quien votar. Hoy hay mucha politiquería, los ataques y el proselitismo político; nombrar las autoridades debe ser porque esto no es malo, los que ya salían electos defendían a capa y espada los derechos de la comunidad con el apoyo que la comunidad misma le brindaba. Hoy vamos por un afán de buscar recursos personales y se gastan recursos con escandalosa campaña y esa plata no sale de cada uno de los candidatos lo que lo considero un escándalo, que esto se dé por terminado liderando el cabildo que aprendieron de las políticas blancas, la competencia, lo que hicieron los politiqueros blancos ${ }^{30}$.

Si bien se encuentran vigilados los espacios de producción de un discurso que permitan el derecho propio, algunos sectores dentro de los Pastos se han movilizado hacia espacios no vigilados, donde tiene cabida la historia oral, el mito, la imagen, la palabra que se escapa al privilegio institucionalizado.

\section{Historia oral (h.o.): apuntes preliminares}

Antes de señalar la relación entre la minga y la historia oral (h.o.), es necesario precisar algunos aspectos teóricos relacionados con esta forma de aproximación al pasado. Al respecto consideramos que la h.o. debe ser entendida como una práctica antes que como una metodología disciplinada, lo que implica advertir las tensiones, su potencialidad y sus límites. interno. 
Thompson (2003), un autor clásico de los estudios sobre h.o., considera que esta puede ser un medio para transformar la estructura de las relaciones académicas, el contenido, el propósito y el enfoque de la historia, y devolver el lugar central a la gente que la vivió. Señala que la h.o. ofrece la ventaja de elegir a quién entrevistar, descubrir fuentes tradicionalmente ignoradas, pensar en la evidencia requerida, buscarla y abordarla desde otro enfoque. Advierte que el mayor mérito que tiene es la recreación de múltiples puntos de vista, en tanto consulta fuentes subalternas, reconstruye el pasado de forma justa, realista y alternativa a la interpretación dominante. Por último, afirma que la naturaleza creativa y cooperativa de la h.o. permite a la academia devolver algo mediante su investigación a los grupos sociales con los que trabaja.

Cercano a Thompson, Portelli (2003) sugiere que la historia oral es útil y diferente porque dice más de los significados que de los eventos en que estos se producen, sin perder validez factual. La h.o. resulta de la relación entre entrevistador y entrevistado, quienes comparten un proyecto mutuo. Así, el contenido de las fuentes orales depende no solo de la pregunta, sino del diálogo y de la relación personal; en vez de descubrir las fuentes, el historiador oral las crea al ser un socio en el diálogo y un organizador del testimonio, al tiempo que el narrador entra al relato convirtiéndose en parte de él. La h.o. se caracteriza por carecer de sujeto unificado, por no poder ser contada sin tomar partida, por hablar desde diferentes puntos de vista y por corroer la imparcialidad tradicionalmente reclamada por los historiadores, reemplazándola por la parcialidad del narrador. La perspectiva de Portelli es relevante en lo que atañe a los temas de esta investigación, ya que permite afirmar la propuesta de una metodología que apela a la conversación producto de la relación. Sin embargo, no se trata de una relación entrevistador-entrevistado, sino de la relación de mutua conversación y aprendizaje, en la que efectivamente, como señala Portelli, hay una creación conjunta del relato.

Carolyn Hamilton (2002), por otra parte, sostiene críticamente que la academia trata la h.o. como fuente inferior. Señala que a este respecto 
no se puede omitir la manera como la cultura material perteneciente a los pueblos es confinada en los museos, lo que afecta los dispositivos de reconstrucción de la memoria e incide negativamente sobre los aspectos orales y performativos del patrimonio vivo inextricablemente vinculado a objetos materiales, lugares, sitios o paisajes. Para la autora, el reto actual de los estudios históricos es trascender los enfoques documentales y evitar que el texto oral se convierta en un documento más. Para alcanzar lo anterior, Hamilton propone discutir el vínculo existente entre palabras y objetos como forma de pensar la memoria social y las reglas que la construyen. Su postura ayuda a entender la complejidad tras un aspecto clave de la historia oral de Cumbal: el relacionado con la piedra de los Machines y la manera como este símbolo de la cultura Pasto es abandonado e incluso subestimado por algunos sectores de la comunidad. Esto pasa al considerar que es más importante hacer vías y comprar maquinaria para infraestructura, que conservar el lugar donde está ubicada la piedra.

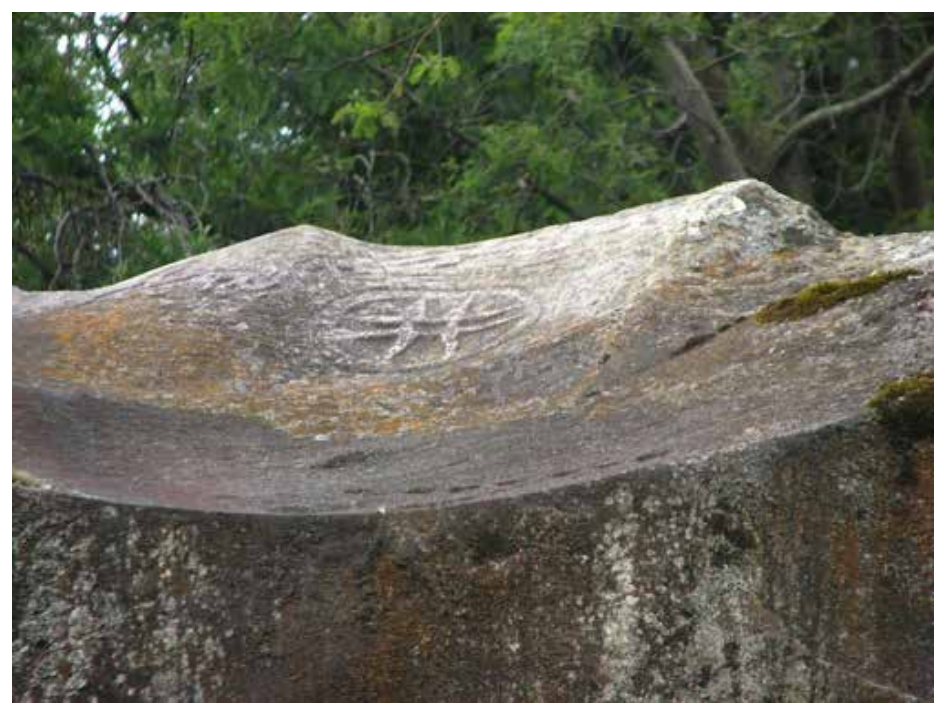



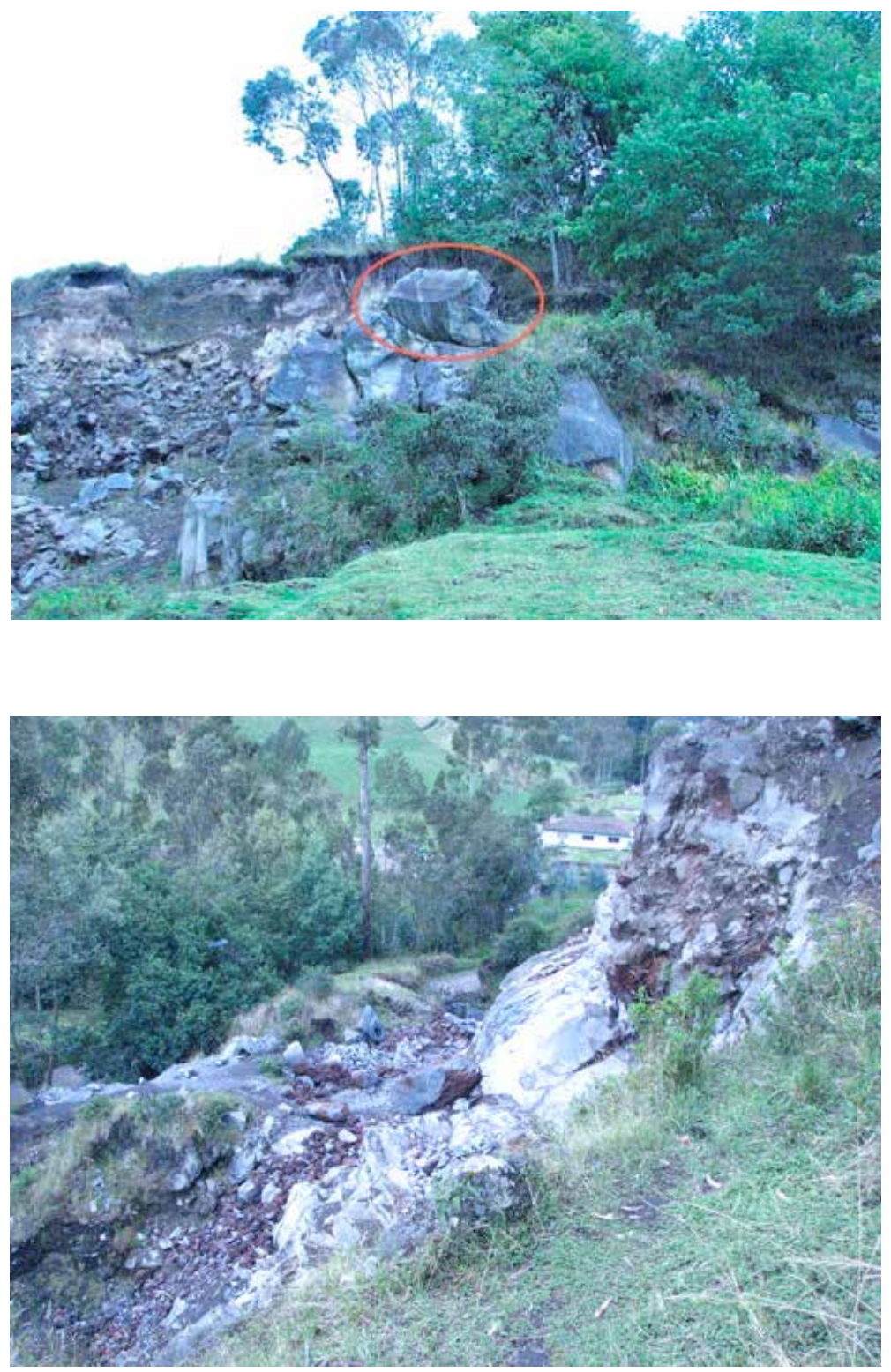

Fotografías tomadas por Óscar López 
Esta secuencia fotográfica la encabeza un acercamiento de primer plano de la piedra de los Machines, con el sol de los Pastos acompañado de unos monos ubicados al costado izquierdo. En la segunda imagen se aprecia (en el ovalo rojo) el riesgo de desprendimiento en el que se encuentra la piedra a causa de la permanente extracción de material rocoso en el lugar. Y, finalmente, se observa el entorno de la piedra, convertido en un depósito de basura. Tomando este caso concreto, la historia oral trasciende del relato a los objetos a través de los cuales se recuerda el pasado de lucha y confrontación para mantener viva en la memoria la batalla librada por recuperar el territorio. Siguiendo a Hamilton, estos objetos se encuentran atados al paisaje para configurarlo de formas que la legislación y la política no logran entender, pero esa es precisamente su mayor potencia como artefactos nemónicos destinados a construir una historia no oficial.

Otro estudio relevante al respecto es el adelantado por Digges y Rappaport (1993), pues en él exploran la estrategia de los Pastos frente al Estado-Nación para recuperar sus territorios ancestrales perdidos en la conformación de la República, la cual consistió en apropiarse y resignificar una tradición legal impuesta durante la Colonia. Para las autoras se trata de una inusual relación entre literalidad, oralidad y práctica ritual, donde estas últimas están codificadas en formas escritas - generalmente legales-, pero su descripción adquiere significado como producto de la práctica oral.

Así, la práctica ritual no es un simple acto de evocación ejecutado con el fin de recordar de forma precisa eventos del pasado, sino una representación de implicaciones políticas en la que confluyen imágenes, actos y palabras en un contexto particular de interacción y construcción de sentidos como estrategia de lucha y supervivencia. Estos planteamientos son fundamentales para entender la manera como se produce un discurso alternativo según el ritual requerido, ritual que la misma comunidad construye o, como en este caso, resignifica, y que se contrapone al procedimiento establecido por el Estado para validar el derecho indígena. 
Mediante las prácticas rituales de apropiación de la tierra, los Pastos se apartan de los lineamientos estatales para reivindicar su derecho sobre el territorio; contienda en la cual la h.o. juega un papel fundamental. En el caso del Consejo Mayor ocurre algo semejante: un sector de la comunidad propone un ritual para pronunciar el discurso del derecho y apartarse de la formalidad institucional que otorga al Cabildo la competencia exclusiva de la jurisdicción indígena. En el momento en que se crea el Consejo Mayor, cuya legitimidad se basa en la historia oral, se rompe la división entre la palabra autorizada y la indecible, entre el discurso que puede ser emitido según las reglas del Estado y el que es pronunciado por fuera de este.

Los Pastos reconstruyen la identidad a través de diversas formas de historia oral que sostienen vínculos políticos e intelectuales con el territorio, las expresiones artísticas y las acciones políticas. Así, se construye un conjunto de relaciones entre el pasado y el presente mediante la evocación, por ejemplo, de la figura mítica del cacique Cumbe como un líder de la resistencia contra el imperio español, figura localizada en el pasado remoto de la comunidad, pero presente en las luchas políticas contemporáneas desarrolladas a través de las mingas. Esta forma de evocar el pasado nos cuestiona por las relaciones de poder comprometidas en la construcción de diferentes sentidos del mismo y sus efectos en las decisiones políticas del presente.

En la experiencia de los Pastos, la interacción de un pasado narrado y re-narrado a través del mito, y un pasado narrado a través de los registros históricos escritos en el territorio como consecuencia del proceso de toma de tierras, incorporan el legado que convoca a la comunidad alrededor de un nuevo proyecto. Este es la expedición de un código llamado por ellos reglamento interno, en el cual convergen diferentes visiones sobre la justicia, la identidad, la minga, el territorio, el pasado y el presente. La producción de este Derecho Mayor —que en sí mismo es una minga - se localiza en registros tanto institucionales como no institucionales. Los primeros siguen el orden legal y político aceptado por 
Estado: el Cabildo, el Consejo Municipal, las organizaciones indígenas, los partidos políticos, entre otros. Los no institucionales surgen de procesos organizativos espontáneos: asociaciones artísticas y comunitarias, carnavales, rituales, mingas, etcétera. Todos estos espacios producen y multiplican un tipo de conocimiento situado, el cual es narrado en niveles metonímicos y metafóricos.

Para incluir las diversas formas a través de las cuales es producido y multiplicado el conocimiento, es necesario tomar en cuenta aquello que Brigs, retomado por Slim y Thompson (1993), describe como el "repertorio comunicativo de las personas” (Slim \&Thompson, 1993 p. 145). Esto refiere a las formas particulares, sus eventos especiales, sus categorías discursivas y sus tabús. Para apreciar este repertorio es necesario ser sensible ante las formas comunicativas y, así, permitir a las personas hablar en sus propios términos; pero, además, rastrear la h.o. en eventos no necesariamente comunicativos en términos verbales, por lo cual es pertinente aludir a las imágenes y al paisaje.

El análisis de los relatos producidos alrededor de la minga entre los Pastos requirió un cuidadoso proceso de interpretación de las metáforas a través de las cuales la gente se expresa. Estas metáforas generalmente apelan a la descripción del territorio, especialmente a las nociones del arriba y del abajo como formas de división de los sentidos simbólicos más que del espacio mismo. Arriba y abajo, como masculino y femenino, blanco y negro, frío y caliente, proporcionan el equilibrio que es representado permanentemente en el lenguaje simbólico usado en los objetos, el paisaje, las manifestaciones artísticas, los mitos y leyendas, entre otras.

\section{Minga e historia oral}

El punto de quiebre con las prácticas culturales está asociado con la manera como se recuerda el pasado, dadas las implicaciones políticas que eso tiene. Un elemento clave entre los mecanismos para recordar, 
evocar y construir el pasado en Cumbal es la historia oral. Al respecto, la oralidad es entendida como un espacio de la cultura andina donde se construye la memoria histórica y, como argumenta Silvia Rivera (1987), es posible recuperar el pasado en tanto fundamento de una identidad cultural y política india, donde es posible comprender mejor el espíritu dinámico que alienta a pueblos como los Pastos. Comprensión que resulta distante de la visión estática y romántica construida por las ciencias sociales.

Dese la orilla opuesta, el Estado multicultural favorece una forma de recordar a través del historicismo en sus diferentes vertientes, y lo que esa forma de recordar impone tiene considerables incidencias en el estilo de vida comunitaria. El multiculturalismo, que se materializa en políticas de la memoria oficial, niega la diferencia que busca subvertir las reglas del Estado-nación; se trata del mismo multiculturalismo que rescata la diferencia convertida en objeto de consumo. Mientras que las condiciones de desigualdad y pobreza promovidas por el liberalismo económico se extienden, el multiculturalismo permanece presente en los espacios de creación colectiva mediante los cuales los Pastos buscan reforzar los vínculos intersubjetivos, reflexionar sobre el gobierno y la autoridad propia y consolidar la justicia indígena.

No obstante, los Pastos, como tantos otros pueblos, se niegan a desparecer en las políticas de mercantilización étnica del Estado. Mediante una constante evocación del pasado que consolida la identidad indígena, sus autoridades, sus mayores, sus jóvenes líderes, se cuestionan acerca de lo que implica políticamente la pérdida de su identidad:

Acá bien sabemos que como indígenas que somos tenemos muchos derechos que hay que fortalecerlos, cultivarlos y cuidarlos a través de mingas de pensamiento, tal y como se han venido dando estas mingas de pensamiento en cada vereda [...] todos somos indígenas o si no queremos ser indígenas hagámonos desconocer del Cabildo y perdamos los derechos que tenemos como indígenas. Compañeros, no llenemos el Cabildo para una 
constancia, para reclamar a mi hijo al cuartel, para la universidad, para todo. Sabemos perfectamente qué derechos tenemos como indígenas, bien saben que el Gobierno nos viene rematando y nos quiere desaparecer como comunidades indígenas; nos desaparecen como comunidades indígenas y quedamos como campesinos aquí y ustedes deben de saber que los campesinos no tienen los mismos derechos que nosotros tenemos ${ }^{31}$.

Un ejemplo de la manera como los pastos construyen una estrategia política de reivindicación a través de la h.o., se encuentra en la minga. Esta expresión cultural es el referente más importante en lo que a formas de organización se refiere; la multiplicidad de los sentidos a ella asociados da cuenta de la complejidad y la riqueza cultural que preserva. Sin embargo, para la academia la expresión minga suele restringirse al trabajo comunitario. Katime y Sarmiento (2005), por ejemplo, proponen "una taxonomía de las entidades de economía solidaria existentes en Colombia” (p.129), dentro de la cual ubican a la minga. Como resultado de la investigación sobre el sector solidario en Nariño, los autores definen la minga como "unión voluntaria de personas que se integran por un determinado tiempo con el fin de desarrollar un trabajo específico para beneficio de la comunidad, quienes pueden aportar con trabajo, medios de trabajo o alimentos” (p.142). Según los autores, el objetivo de la minga es satisfacer las necesidades de la comunidad mediante la construcción de infraestructura, vías, edificios, en búsqueda de "el progreso y desarrollo de la región y el ahorro de costos”, y que por tratarse de una costumbre social "no ha existido norma que la regule" (p.142). Condición que los autores echan de menos.

Mora et al. (2005) señalan que la minga entre los Pastos adquiere diversos sentidos; no obstante, abordan esta compleja manifestación cultural desde una perspectiva predominantemente económica. Entre las clases de mingas que los autores reconocen se encuentran las de caciques,

31 Cabildante participante en el taller del Llano de Piedras. Junio de 2011. 
cabildo, hacer o arreglar puentes, del pensamiento, de marchas. La intención de los autores es ofrecer argumentos que permitan visibilizar la minga como una forma de trabajo solidario reglamentada por el derecho estatal para garantizar así condiciones económicas equitativas a sus participantes, como sucede con las demás formas de trabajo solidario.

La manera como la minga ha sido estudiada por la economía y el derecho revela un sesgo reduccionista que oculta la multiplicidad de sentidos de la minga, aunque no todos ellos ligados a lo económico. En el caso de los Pastos la minga adquiere diversos significados: protesta y movilización, reuniones con fines deliberativos o de reflexión (minga de pensamiento), recolección de una cosecha, construcción de una casa o una vía, trabajo previo a una fiesta (mingas de dulce), entre otros. Todos estos significados anclados a los elementos propios de la cultura de los Pastos, trascienden la repartición colectiva del trabajo comunitario; por ello, para los Pastos, la minga es un principio de vida:

Este principio es uno de los más importantes que se debe mantener dentro de la población, el cual enlaza la vivencia colectiva de un pueblo o comunidad, la que soporta sus trabajos de construcción de las casas, de sus shagras, de arreglos de los caminos, de generar un bienestar colectivo. Por lo anterior se puede afirmar y a la vez se propone que la minga es y debe seguir siendo el camino por donde transite el quehacer colectivo. Decimos, entonces, que este principio, desde nuestros tiempos antiguos, nos socializa y arroja el valor de vivir en sociedad, en una convivencia; un valor económico, conocimiento y productividad ${ }^{32}$.

La minga subsiste en la tradición oral de los Pastos como elemento de cohesión social y construcción de identidad; por y en ella se tejen los vínculos entre los individuos y la tierra, al tiempo que se realiza la justicia material. Recíprocamente, la minga mantiene viva la memoria

32 Fragmento de las intervenciones producidas en las mesas de trabajo conformadas en el 2007 para la expedición de la Ley Interna. 
histórica al renovar constantemente los vínculos intersubjetivos ligados por una experiencia de despojo compartido y de resistencia contra la proletarización y expropiación de la tierra. Por esto, la minga adquiere una dimensión política vivencial.

En entrevista realizada a don Abraham Tarapues en abril de 2008, al preguntarle por las mingas, él sostuvo que existen las mingas de leña y de dulce. Estas formas organizativas están dedicadas a la celebración de festividades. Según don Abraham, su origen se remonta a una imposición hecha por la iglesia católica, y en algunas ocasiones por las autoridades locales, mediante la cual los integrantes de la comunidad debían "ofrecer" las fiestas de los días previos a la navidad, conocidas como veladas del niño. Para la realización de estas veladas se designaba un fiestero, quien usualmente contraía cuantiosas deudas económicas para cubrir los gastos ${ }^{33}$. Pero al respecto es importante señalar que en esta práctica se ponía en riesgo el patrimonio del designado, lo que ocasionaba conflictos, por lo que llegó a prohibirse en algunos resguardos la celebración de estas fiestas. Ante esa prohibición, explicaba don Abraham, la comunidad comenzó a pensar en la celebración de veladas en las que interviniera la comunidad para reducir los gastos, y fue así como comenzaron a desarrollarse las mingas de leña y dulce con propósitos festivos.

La minga es una tradición aun conservada por personas como don Fidel Chalparizal, de la misma vereda de Cuetial, quien señala: “Todos los trabajos se hacían en mingas, las shagras, las zanjas y demás; y se hacían mediante la colaboración de los vecinos. Si la minga no era grande se prestaban los días, que luego el vecino devolvía. No existía el con-

33 Persona de la comunidad que ofrece la fiesta y quien debe asumir los gastos de la misma (comida, bebida, pólvora, música, pago de dos ceremonias religiosas, una a las 6:00 p.m. y otras a las 6:00 a.m. del día siguiente). Pese a las consecuencias ya señaladas sobre esta práctica, ofrecer la fiesta otorga reconocimiento y prestigio dentro de la comunidad. 
cepto de jornal ni salario, todo era un trabajo comunitario" ${ }^{4}$. En este caso, la minga se realiza con finalidades próximas a las tradicionalmente asignadas en el imaginario académico. Sin embargo, pareciera que la minga, como forma de organización del trabajo, ha perdido fuerza entre la comunidad, lo cual concuerda con el panorama actual:

Se ha perdido [la minga] porque en la misma vereda había personas que pagaban por el trabajo mediante el jornal, lo que entorpeció las costumbres ancestrales. Cada uno ya tenía sus propios recursos. Lo otro es que eran menos los habitantes y era más fácil la comprensión, hoy son nuevas costumbres, y el personal se ha tratado de civilizar y la costumbre de servidumbre a los vecinos ya no fue colaborativa. El que recogía decía "yo no regalo mi trabajo"35.

La afirmación de don Fidel coincide con la que años más tarde manifestaba don Salomón Cuaical:

Pero, más sin embargo, por nuestra desorganización ha habido gente que se ha aprovechado. Ha habido gente que ha invadido nuestro territorio y ha invadido nuestros usos y nuestras costumbres, ustedes se pueden dar cuenta que por el avance de la tecnología se están perdiendo los usos y las costumbres, por ejemplo más antes las mingas eran bien concurridas y ahora casi ni se ven más ${ }^{36}$.

¿Qué provoca la extinción progresiva de las mingas como forma de trabajo comunitario? No parece existir una causa única. Para algunos líderes, como Luis Alpala, se trata de los efectos causados por el ingreso de dineros públicos a las comunidades indígenas. Según él, si bien antes de la Constitución de 1991 estas carecían de recursos económicos para realizar obras públicas, la carencia instaba a la recuperación y, en

$34 \quad$ Entrevista personal. Abril de 2008.

35 Entrevista personal. Abril de 2008.

36 Intervención de Salomón Cuaical en el taller del Llano de Piedras. Junio de 2011. 
otros casos, a la conservación de tradiciones asociativas en procura de fines comunes. La minga era un recurso necesario para la construcción de una vía, un acueducto, la casa del Cabildo, entre otras; tanto como sucedía con la realización de una labor que en principio implicaba un beneficio particular, como la recolección de una cosecha, la construcción de una zanja o la reparación de una casa.

Don Fidel Chalparizal, al preguntarle por las acciones adelantadas por el Cabildo en su época de regidor para conservar las mingas, señalaba lo siguiente:

En el tiempo que yo estuve como regidor no se llegó a tocar ese punto, en ese tiempo eran otros pensamientos por motivo de que no estábamos demasiado concentrados en los recursos económicos, pienso yo que conforme se vino la oportunidad de los recursos de transferencias y de la organización territorial, entonces ya los que se prepararon a nivel universitario ven la necesidad de volver a reorganizarse la comunidad ${ }^{37}$.

\section{En la shagra de don Fidel: caminando la palabra}

Una característica que parece distintiva entre los Pastos es su capacidad para combinar los conocimientos tradicionales con las técnicas desarrolladas por la agronomía, la agroecología y otras disciplinas. Don Fidel Chalparizal explica la manera como él combina los conocimientos brindados por las instituciones públicas y los resultados obtenidos mediante las prácticas por él desarrolladas tras décadas de observación y experimentación:

Cuando yo estuve de regidor tuve la oportunidad de pedir una capacitación y la aproveché. Yo acudí a las capacitaciones, pero nunca quedé con una teoría que nos dio un profesional escrita en una hoja de papel, sino que todo se aprovechó, y con base en ello tuve en cuenta la reforestación, la recupe- 
ración de recursos naturales. ¿Qué hice yo? Me salí del bloque de los demás regidores y del taita gobernador. Entonces, yo me dirigí ante Corponariño y solicité de nuevo una consulta, le expuse el problema y arrancamos en la producción de árboles nativos, rescatando especies que estaban a punto de perderse. Y seguimos hablando del recurso hídrico, porque estábamos pensando en la posibilidad de hacer un acueducto pero sin seguir tumbando el monte. Pero concientizamos a la gente de proteger los nacimientos de agua, al tiempo que se solicitaba al gobierno unos recursos para construir el acueducto. Corponariño se comprometió a comprar los árboles a cambio de que la comunidad se comprometiera a reforestar las partes altas, y por la siembra darían los recursos para la construcción del estanque. La gente comenzó a construir los estanques acá en Cuetial. En principio los estanques tenían un alcance no comercial, más bien de nutrición para la familia, y se logró promover la recuperación de la vereda. Cuando [yo] tenía la edad de unos 36 años esto era un peladero completo, y ahora usted lo ve y no solo tiene árboles nativos, sino exóticos: pino ciprés, y en la vereda ya no sufrimos de verano tan extenso porque hay sombra de los árboles. Entramos a trabajar en nuestra experiencia con arborización, lo que se llama barreras rompeviento, barreras vivas o barreras linderos, para que sirvan de sombrío para los animales en la hora que haga sol pues ahí se defienden del calor; o otro, es que sirven para cuando hacen esos vientos demasiado extensos, para que no erosionen la tierra. Además ahí se generan las diferentes especies de aves y esas son las que nos ayudan al control biológico de nuestras cementeras, porque ya utilizar plaguicidas comerciales no da resultado porque crearon resistencia, y si liquida uno, ya aparece otro más aguerrido, entonces lo que es con el control de los bichos pues es importante que así se ha controlado, por eso es de que ahora estamos trabajando principalmente con abonos producidos aquí en la finquita. Ya tenemos construida la marranera, de allí sacamos el estiércol, luego lo colocamos en el extractor, aprovechamos el gas en combustible para cocil, y ese líquido biodigestor lo sacamos en unas piletas donde tenemos almacenado aserrín desechado por los aserraderos y lo colocamos con cal, y cada quince u ocho días sacamos el biolíquido del biodigestor y estamos construyendo un excelente abono, y de allí la meta nuestra es sacar un líquido para fumigar las plagas de los cultivos ${ }^{38}$. 
El relato de don Fidel juega con la temporalidad, va y viene entre sus años de juventud, cuando su memoria trae el recuerdo de la deforestación de Cuetial y de la falda del Cumbal — hectáreas deforestadas luego del temblor de 1923 - y cuando los colonos obligaron a los Pastos a ocuparlas $^{39}$. Si el derecho estatal intenta regular el tiempo de la vida a la manera de un proceso judicial, la narración de don Fidel muestra la manera en que las prácticas por él desarrolladas hacen uso distinto del tiempo. Don Fidel, como muchos agricultores de Cumbal, no tiene afán de aumentar la producción ni tampoco de acelerar la cosecha. El problema para ellos es claro: no se trata de cosechar más papas o verduras ni de vender más truchas o más cerdos, el problema es cómo hacer para que las papas, la verduras, las truchas y los cerdos se cosechen o nazcan y se reproduzcan en una proporción que garantice un consumo sostenible para la tierra y para las especies que en ella habitan, no para la rentabilidad del mercado. Ese es uno de los sentidos que se manifiesta al hablar de otras temporalidades en juego.

La memoria de don Fidel regresa al presente para explicar la manera en que ha aprovechado, pero también actualizado, los conocimientos que Corponariño le brindó:

Lo que aprendimos todo fue por solicitud que hicimos a las autoridades y entidades gubernamentales, eso es justo reconocerlo; que no fue Fidel Chalparizal que se lo inventó y por obra del espíritu santo se lo llevó a la cabeza. Entonces, las personas profesionales nos han traído ese conocimiento y nosotros lo hemos sabido aprovechar, pero no nos hemos quedado únicamente con la teoría que nos enseñaron, con las prácticas que ellos nos trajeron, sino que a mí me ha servido de herramienta como para seguir mi investigación, porque aquí yo trabajo con mi yerno y dice "no pero si el ingeniero, el doctor dijo...”. Hay que aprender más allacito de dónde nos da la luz el sombrero, demos otro paso más. Esa ha sido una grande experiencia,

Para una revisión más detenida de lo ocurrido tras el temblor de 1923, se sugiere López (2011). 
una gran acogida que yo he tenido con instituciones del Gobierno que me dicen "y aparte de lo que le enseñamos nosotros ¿quién le vino a enseñar esto?” No, pues yo lo aprendí, que ¿cómo lo aprendió?, ¿dónde lo miró?, es que uno dañando se aprende, hacemos nuestra propia investigación. Yo nunca he sido una persona que me quedo con la explicación o con lo que me recomiendan, aun cuando me demore mi tiempito yo lo pongo a funcionar, por eso en cuestión de árboles nativos tenemos una grande experiencia que de pronto Corponariño no logró a descubrir todo el proceso de lo nativo, en cambio nosotros si aprendimos. Como es a largo plazo entonces aprendimos a investigar la planta, ya sabemos qué semillas, a qué tiempo germinan, con qué clase de insumos se pueden trasplantar, hay semillas nativas que no se les puede aplicar nada químico, todo tiene que ser natural; y lo otro, la producción de semillas que tiene cada uno su tiempo, entonces son experiencias que nosotros mismos obtuvimos ${ }^{40}$.

El relato de don Fidel revela la forma distinta de comprender los tiempos que persisten en la cultura de los Pastos. La resistencia al ritmo y a la temporalidad impuesta por las instituciones de Gobierno le permite aprender, experimentar, equivocarse y, finalmente, obtener la mejor productividad de su shagra. En tanto no obtiene grandes volúmenes, sino una producción de alta calidad, respeta la fragilidad y los equilibrios de la misma tierra. El sentido del largo plazo, impensable para los precipitados ritmos de producción industrial que se imponen en el sector agrario, hoy en su mayoría con fines de exportación, son ignorados por don Fidel; no porque ignore su existencia, sino como un acto de resistencia.

El relato de Fidel Chalparizal nos pone ante una batalla epistemológica. Él, como muchos otros, hace su propia investigación: observa, se toma el tiempo, experimenta, cambia de estrategia, anota los resultados. Aquello que el positivismo científico reclama como de su autoría es disputado en las prácticas cotidianas mediante el uso del sentido co- 
mún. Don Fidel aprende y enseña al mismo tiempo, dialoga, discute sus teorías, intercambia conocimientos que de otra manera le resultarían a Corponariño imposibles de adquirir.

Ahora bien, la forma como se transmite y se conserva ese conocimiento es una minga, tal y como lo explica don Fidel al preguntarle por la manera como él desarrolló ese saber:

Afortunadamente nunca he sido un tipo egoísta, eso sí, con todo mundo lo que me preguntan yo le doy todo el detalle aún más explicadito, porque a veces no preguntamos lo principal, entonces yo le digo "no mire, empecemos ende aquí”, y la parte intermedia hasta el final, por lo que somos visitados por bastantes personas de aquí de Nariño. Hace unas semanas nos visitaron del norte de Nariño, por copiar el trabajo y hacer la propia investigación porque ese ha sido el fin de mi persona: compartir, convivir con la naturaleza y colaborarle a la gente, a los que quieren seguir, mirar y me preguntan y yo no vacilo; les doy toda clase de explicaciones porque uno nada ganaría con aprender y reservárselo ya el conocimiento.

De eso se trata la minga, una conversación sin restricción, la palabra en fuga, sin sistemas de exclusión que regulan lo que se puede o no se puede decir. Para don Fidel todo el producto del conocimiento se puede nombrar, todo se puede compartir en la conversación. Don Fidel descapitaliza la relación mediante el acto de enunciación sin censuras y sin restricciones, sin propiedad privada sobre la lengua. El acto de enunciación, así como el trabajo de su shagra —que estaría incompleto sin compartir el conocimiento que ella produce-, dan sentido a la vida de don Fidel, pues le permiten romper cualquier relación de deuda. Don Fidel no le debe a nadie, no es el hombre endeudado del que nos habla Lazzarato (2013) como el sujeto icónico de nuestra época. Además, él es un ejemplo por medio del cual se comprueba la esencia existencial de la minga, la cual, engastada en la memoria de los Pastos, es mucho más que una forma de trabajo colectivo, comunitario o resistente al capitalismo. La minga es más que un espacio inaccesible para las relaciones 
de producción hegemónicas. En ella subyacen múltiples sentidos y sentimientos, una complicidad tejida en las relaciones cotidianas de vecindad, en la memoria producto de una experiencia de despojo compartida.

La minga no necesita ser nombrada, clasificada, mucho menos reglamentada o incluida en el monolingüismo jurídico. La minga está presente en la capacidad de compartir el conocimiento, como la prueba de que el fin de la persona es compartir, pues es un fin en sí mismo que se mantiene potente, incluso en su condición marginal, porque no se puede codificar por el derecho estatal. De regularla quizás la minga se inscribiría en una relación de intercambio comercial, de valores de cambio. Pero aún mantiene su potencia alterativa porque no hace parte de una pulsión individual, sino de una instrucción colectiva que se refresca mediante la palabra, la memoria, la historia oral, las imágenes y el mito, así como de las prácticas cotidianas. Es la voz de los mayores que sigue siendo escuchada, es el trabajo de los líderes que mantiene su credibilidad ante la comunidad de Cumbal porque participan del Cabildo, pero también de la shagra: en la fiesta pero también en la minga. Son esos referentes, los que siguen dando legitimidad a la minga, lo que hace innecesario e incluso pernicioso regularla a través del derecho estatal que pretende revestirla de un estatus legal. ¿Qué necesidad habría si ya tiene un lugar en las prácticas, en eso que llamamos la cultura andina?

Actualmente los Pastos tienen la titulación de gran parte del territorio ancestral, ese mismo que al parecer ocuparon durante siglos antes de la colonización y la consolidación de la República. Sin embargo, el reconocimiento de los derechos culturales y políticos que alcanzaron tras la recuperación genera divisiones entre los Pastos, ahora enfrentados por aquello que recuperaron mediante un proyecto colectivo y un uso alternativo de la historia.

No obstante, la minga se defiende, pues al indagar por ella entre los pobladores de Cumbal es posible encontrar una multiplicidad de historias, 
relatos diversos e incluso contradictorios. Es necesario acudir a las herramientas de la historia oral, en tanto la minga está engastada en la memoria del pueblo de los Pastos como un espacio de creación política y social. Sabemos que hay mucho por indagar al respecto, y que dados los procesos culturales e históricos del país, este parece ser un momento de consolidación de un proyecto de ordenamiento interno, de saneamiento del territorio y de consolidación de la justicia entre los Pastos.

\section{Bibliografía}

Alpala, M. A. (2008). El Derecho Mayor en el "Pueblo Indígena de los Pastos". Ipiales: Cedigraf Editores.

Arteaga, J. B. (1910). Apuntamientos sobe Mayasquer y Cumbal. Pasto: Imprenta del Departamento.

Barona, G. y Rojas, T. (2007). Falacias del pluralismo jurídico y cultural en Colombia. Ensayo crítico. Popayán: Universidad del Cauca.

Briones, C. (1998). (Meta)cultura del Estado-nación y estado de la (meta)cultura. Brasilia: Serie antropología.

Calero, L. F. (1991). Pastos, Quillacingas y Abades. 1535-1700. Bogotá: Fondo de Promoción a la Cultura, Banco Popular.

Cerón, B. y Zarama, R. (2003). Historia socio espacial de túquerres siglos XVI$X X$. De Barbacoas hacia el horizonte nacional. Pasto: Universidad de Nariño.

Chamorro, D. y Erazo, M. (1982). Elementos para la interpretación de la historia de Nariño: Provincia de los Pastos. Finales del periodo colonial. Pasto: Fundación para la Investigación y el desarrollo cultural de Nariño. FINIC.

Cieza de León, P. (1962). La crónica del Perú. Madrid: Colección Austral.

Cifuentes, G. (2004). Los Calvijos. En Antología histórica. Insurrección comunera exprovincia de Túquerres 18, 19, 20 de mayo de 1800. (Comp. Asociación de trabajo Prosperar). 30-48.

Digges, D. y Rappaport, J. (1993). Literacy, Orality and Ritual Practice in Highland Colombia. En J. Boyarin. (Ed.) The Ethnography of Reading (pp.139-155). Los Angeles: University of California Press. 
Gómez, L. (1985). Parentesco y relaciones económicas en la comunidad indígena de Muellamues. Tesis de pregrado en antropología Universidad Nacional de Colombia, Bogotá.

González, F. (1902). Los aborígenes de Imbabura y Carchi. Quito: Casa de la Cultura Ecuatoriana.

Gros, C. (1997). Indigenismo y etnicidad: el desafío neoliberal. En M. V. Uribe y E. Restrepo. (Eds.) Antropología en la modernidad: identidades, etnicidades y movimientos sociales en Colombia. Bogotá: ICANH.

Groot de Mahecha, A. M. y Hooykaas, E. (1991). Intento de Delimitación del Territorio de los Grupos Étnicos Pastos y Quillacingas en el altiplano nariñense. Bogotá: Fundación de Investigaciones Arqueológicas Nacionales.

Guerrero, G. L. (1998). Estudios sobre el municipio de Cumbal. Bogotá: Internacional de Impresores El Dorado

Guerrero, M. T. (2012). La historia por contar sobre el "sol de los pastos”. En Pensamiento, Historia y Cultura de los pueblos Pastos y Quillacingas. Memorias del Simposio. Pasto: Academia Nariñense de Historia.

Gutiérrez, J. (2007). Los indios de Pasto contra la República (1809-1824). Bogotá: ICANH.

Hale, C. (2002) ¿Puede el multiculturalismo ser una amenaza? Gobernanza, derechos culturales y política de la identidad en Guatemala. en: Maria L. Lagos, Pamela Calla (comps.), Antropología del Estado: dominación y prácticas contestatorias en América Latina. 286-346. La Paz: INDH/PNUD

Hamilton, C. (2002). Living by Fluidity. Oral histories, Material Custodies and the Politics of Archiving. En C. Hamilton, V. Harris, C. Printers, C. (Eds.) Town Refiguring the Archive. London, Kluwer Academic

Katime, A. y Sarmiento, A. (2005). Hacia la construcción del derecho solidario en Colombia. Medellín: Universidad Cooperativa de Colombia, Dansocial.

Landázuri, C. (1990). Territorios y pueblos: la sociedad pasto en los siglos XVI y XVII. Quito: Instituto de Antropología Andina.

Lazzarato, M. (2013). La fábrica del hombre endeudado. Ensayo sobre la condición neoliberal. Buenos Aires: Amorrortu.

Lemaitre, J. (2009). El derecho como conjuro. Fetichismo legal, violencia y movimientos sociales. Bogotá: Siglo del Hombre Editores, Universidad de los Andes. 
López, O. (2011). Genealogía de un Temblor. En Revista de la Facultad de Derecho y Ciencias Políticas y Sociales. Número 11 Volumen 16 y 17. Popayán: Universidad del Cauca

López, O. (2011b). Los cantos de sirena del multiculturalismo jurídico político. La identidad cultural en la jurisprudencia de la corte constitucional. En Revista Tabula Rasa. (14) Bogotá: Unicolmayor.

López, O. (2016). Narrativas académicas e historia oral en el pueblo de los Pastos. En Revista Antípoda. (25) Páginas 75-96

Mamián, D. (1996). Geografía Humana de Colombia, Región Andina Central. Tomo IV, I, (pp.9-118). Bogotá: Instituto Colombiano de Cultura Hispánica.

Mamián, D. (2004). Los Pastos en la danza del espacio, el tiempo y el poder. Pasto: Ediciones Unariño.

Martínez, E. (1977). Etnohistoria de los Pastos. Pasto: Editorial Universitaria.

Mejía, J. (1934). Ensayo sobre la prehistoria nariñense. Pasto

Mora, E. y colaboradores. (2005). La minga, como entidad autóctona del derecho y de la economía solidaria. Tesis de pregrado en Derecho. Pasto: Universidad Cooperativa.

Moreno, S. (1999). Las sociedades de los Andes septentrionales. En Historia General de América Latina. Las sociedades originarias. 1, pp.359-385. Madrid: Trotta, Ediciones UNESCO.

Muñoz, L. (1982). La última insurrección indígena anticolonial. Ensayo histórico sobre la provincia de los Pastos siglos XVIII y XIX. Pasto: Imprenta del Departamento, Casa de la Cultura de Nariño.

Muñoz, L. (2004). Participación social y de género. En Antología histórica. Insurrección comunera exprovincia de Túquerres 18, 19, 20 de mayo de 1800. Túquerres: Alcaldía Municipal de Túquerres. Secretaría de Educación y Cultura Municipal, Asociación de Trabajo "Prosperar".

Muñoz, L. (2011). Mujeres del sur en la independencia de la Nueva Granada. San Juan de Pasto: Graficilor.

Muñoz, L. (2012). Desde el tiempo del encantamiento en territorio Quillasinga. Imaginarios de la Cocha. En Pensamiento, Historia y Cultura de los pueblos Pastos y Quillacingas. Memorias del Simposio San Juan de Pasto 28, 29 y 
30 de junio de 2011. San Juan de Pasto: Gobernación de Nariño y Academia Nariñense de Historia.

Pérez, A. (1958) Contribución al conocimiento de la prehistoria en los pueblos del norte del territorio de la República del Ecuador. Llacta, Cumbal.

Portelli, A. (2003). What makes oral history different. En R. Perks y A. Thomson. (Eds.) Oral history reader. London, Routledge.

Rappaport, J.. (2005). Cumbe Renaciente. Una historia etnográfica andina. Bogotá: ICANH,

Rivera, S. (1987). El potencial epistemológico y teórico de la historia oral: de la lógica instrumental a la descolonización de la historia. En Revista PeriFeria, No. 4. Neiva, agosto-diciembre de 2004, pp. 16-26.

Slim, H. y Thompson, P. (1993). Ways of listening. En O. Benet y N. Cross. Listening for Change: Oral History and Development (pp. 61-94). Londres: Panos.

Solarte, A. y colaboradores (1999). La huella de los Pastos: un pueblo de raíces profundas y de inmensas proyecciones al futuro. Pasto: Editorial Graficolor,

Thompson, P. (2003). The voice of the past. Oral history. En R. Perks y A. Thomson (Eds.). Oral history reader. London, Routledge.

Uribe, M. V. (1986). La estratificación social entre los Proto-Pasto. En J. Alcina Franch y S. Moreno Yañez (comps.) Arqueología y Etnohistoria del sur de Colombia y Norte del Ecuador. Quito: Banco Central del Ecuador, Ediciones Abya-Yala.

Van Cott, D. L. (2000). Latin America: constitutional reform and ethnic right. En Parliamentary Affairs 53 pp. 41-54

Wade, P. (2006). Etnicidad, multiculturalismo y políticas sociales en latinoamérica: Poblaciones afrolatinas (e indígenas). En Revista Tabula Rasa. (14) Bogotá: Unicolmayor. Páginas 59-81

\section{Documentos del pueblo de los Pastos}

Ley Interna Derecho Mayor del Resguardo del Gran Cumbal “Por la cual se regulan las funciones de las Autoridades Indígenas, la creación del 
Consejo Mayor, las Elecciones de la Corporación del Cabildo, la Población y el Censo del Resguardo del Gran Cumbal”.

Asociación de Cabildos y Autoridades Tradicionales del Nudo de los Pastos SHAQUIÑAN. Plan Binacional para el fortalecimiento Cultural, Natural y Ambiental del Nudo de los Pastos. 